\title{
The Institutionalization of Symbolic InTERACTIONISM In CANADian Sociology, 1922-1979: Success at What Cost?
}

\author{
Richard Helmes-Hayes \\ EMILY MiLnE
}

Abstract. This essay examines the growth of symbolic interactionism (SI) as a specialization in English-language Canadian sociology, 1922-1979. We do not focus on theoretical and/or methodological developments. Rather, we document three empirical indicators of the institutionalization of SI: faculty members hired, research published, and SI-receptive programs established. We find that Canadian sociologists institutionalized SI in two phases. From 1922 to 1959, SI institutionalized slowly. There were few SI "core" faculty and scarcely more "SIaccommodative" faculty. Little SI-based literature was published. McGill had Canada's only SI-friendly program. After 1960, SI grew rapidly and, by 1979 , was well institutionalized: over ninety SI and SI-accommodative faculty had been hired, SI literature (journal articles, textbooks) was commonplace. Many sociology departments offered an SI-accommodative program. Sometime in the 1980s, classical SI began to "de-institutionalize." Ironically, as SI's footprint grew and influence spread, it appeared to become less discernable, less coherent and less viable as a distinct and unified approach.

Keywords: History of Canadian sociology; symbolic interactionism; institutionalization; Chicago School

Résumé. Cet article traite de l'essor de l'interactionnisme symbolique (IS) en tant que courant spécialisé de la sociologie canadienne de langue anglaise, sur la période 1922-1979. Il ne s'agit pas ici de se centrer sur des développements théoriques et/ou méthodologiques inhérents à ce courant, mais plutôt de travailler sur trois indicateurs empiriques de l'institutionnalisation de l'IS: le recrutement de professeurs représentant ce courant, les publications qui lui sont liées, et enfin les programmes académiques ouverts à son influence. Les sociologues canadiens ont institutionnalisé l'IS en deux phases. De 1922 à 1959, l'IS a fait l'objet d'une institutionnalisation lente. Il n'existait que peu de représentants typiques de ce courant au sein du monde académique, et à peine plus nombreux étaient ceux qui y étaient accommodatifs. Il y avait peu de littérature représentant l'IS et seule McGill disposait d'un véritable programme représentant ce courant. Après 1960

(C) Canadian Journal of Sociology/Cahiers Canadiens de sociologie 42(2) $2017 \quad 145$ 
en revanche, l'IS se développe rapidement et s'institutionnalise efficacement ; ce qui fait qu'en 1979, on ne trouvait pas moins de 90 professeurs interactionnistes symboliques ou accommodatifs à ce courant, tandis que la littérature (articles ou manuels) était devenue abondante. De nombreux départements avaient créé un programme influencé par l'IS. Pourtant, à partir des années 1980, ce courant qui s'était imposé commence à se «désinstitutionnaliser». Ironiquement, c'est en effet l'extension même de l'empreinte de l'IS et de son influence qui tend à le dissoudre en quelque chose de moins reconnaissable, de moins cohérent et finalement de moins viable en tant qu'approche originale et uniforme.

Mots cles: Histoire de la sociologie canadienne; interactionnisme symbolique; institutionnalisation; École de Chicago

\section{INTRODUCTION $^{1}$}

In this essay we examine the establishment and growth of symbolic interactionism (hereafter SI) as a specialization in English-language Canadian sociology, 1922-1979. ${ }^{2}$ Much research has been undertaken in the United States with regard to the history, theoretical development and institutionalization of $\mathrm{SI}^{3}$, but no equivalent published work has been undertaken in Canada. We fill this gap not by discussing theoretical and/ or methodological developments - the usual approach taken by theorists and historians - but by documenting three empirical indicators of the institutionalization of SI in Canada: faculty members hired, research published, and SI-accommodative programs established.

Our documentation of the institutionalization of SI is intended to: 1/ fill a gap in the history of Canadian sociology; 2/ contribute to the historical study of SI as a sub-disciplinary specialization within the Chicago

1. Fatima Camara and Rick Helmes-Hayes presented a conference paper on this topic in 2003. We make no use of the data upon which the 2003 paper was based. We acknowledge with thanks Ms Camara's permission to use the interviews from that project. As well, we would like to thank Tim Gawley, David Nock, Dorothy Pawluch, Tony Puddephat, Billy Shaffir and Robert Stebbins who commented on early iterations of this essay. Finally, we offer sincere thanks to the three scholars who generously agreed to review our manuscript and to Kevin Haggerty, editor of the CJS, for their thoughtful comments and advice.

2. We neither examine the profile of SI in cognate disciplines (e.g. anthropology) nor describe the meagre profile of SI in French-language Canadian sociology (re the latter, see van den Hoonaard; cited Vannini 2008: 8).

3. Scholars disagree about how to define SI and, thus, about who counts as a symbolic interactionist. See Methodology: Research techniques: 1. Identification of SI community members for the criteria we used. 
$\mathrm{School}^{4}$; 3/ outline a historical-theoretical framework for examining the institutionalization of an academic specialty; and 4/ provide a baseline measure of institutionalization from which the question of SI's broader influence could be studied.

Our Literature Review has two parts. The first overviews research in the history of English-language Canadian sociology relevant to our analysis of the institutionalization of SI in Canada. The second reviews approaches scholars have used to document and assess the development of "theoretical traditions" in sociology. In this section, we pay detailed attention to the complementary work of Harry Hiller $(1980,1982)$ and Nicholas Mullins (1973) for, in the following section, we combine their approaches to create a framework for describing the institutionalization of SI in Canada. In the two subsequent sections, we outline our method and report our findings. In the Conclusion, we use Gary Alan Fine's work (1993) regarding the decline of SI in the United States in the late twentieth century to provide a framework for our discussion of what we see as the slow fading of classical, especially Blumerian, SI in Canada since the mid-to-late 1980s.

Our data indicate that SI institutionalized in two phases. From 1922 to 1959 , the discipline was poorly developed and SI institutionalized slowly. There were few SI "core" faculty and scarcely more "SI-accommodative" faculty. ${ }^{5}$ Most were based at McGill. Little SI-based literature was published and only McGill had a truly SI-friendly program. After 1960, however, SI developed quickly and, by 1979, was well institutionalized. There were over ninety SI and SI-accommodative facultymore than two dozen of them core symbolic interactionists - across the country. Mainstream Canadian sociology journals reported SI-type research on a relatively frequent basis. SI scholars had begun to produce SI-based textbooks. About half of Canadian sociology departments with graduate programs had sufficient faculty and courses in place to offer an SI-accommodative program. However, sometime during the eighties, SI, especially in its Blumerian form, began to fade - to "de-institutionalize" - as those working within the tradition increasingly adopted elements of other approaches, especially feminism and postmodernism. After SI's footprint had grown and its influence spread, it appeared to

4. There is an enormous body of literature on the Chicago School, including the "second Chicago School." Useful general sources include Faris (1970), Matthews (1977), Fisher and Strauss (1978), Lewis and Smith (1980), Bulmer (1984), Kurtz (1984), Harvey (1987), Plummer (1991, 1996), Fine, ed. (1995) and the introduction to Low and Bowden (2013).

5. Re: our use of the term "SI-accommodative" faculty, see the Methodology section. 
become less discernable, less coherent, and less viable as a distinct and unified approach.

\section{Literature ReViews}

\section{The history of Canadian sociology}

There is no comprehensive history of English-language Canadian sociology. There are overviews of various kinds, but most are brief and few are useful for our purpose (e.g. Falardeau and Jones 1958; Forcese and Richer, eds. 1975: 449-66; Clark 1975, 1979; Tomovic 1975; Ramu and Johnson 1976: 479-94; Symons 1977; Brym 1979, 1986, [with Fox] 1989; Hiller 1980, 1982: 3-63; Rush, Christiansen and Malcolmson 1981; Wilcox-Magill 1983; Bodemann 1984; Helmes-Hayes 2003; Platt 2006; Carroll 2013; Helmes-Hayes and Warren, in press). Other scholars have documented key events in the history of the discipline such as the founding of the Canadian Sociology and Anthropology Association (hereafter CSAA) (Jones 1990), the establishment of the Canadian Review of Sociology and Anthropology (Jones 1992), and the dynamics of the "Canadianization movement" that convulsed the discipline in the 1970s (e.g. Hiller 1979; Grayson and Magill 1981; Cormier 2004). As well, scholars have described theoretical, methodological, and substantive developments in numerous subject areas including class analysis, political economy, demography, race and ethnic studies, and feminist sociology (e.g. Langford 2013; Marchak 1985; Wargon 2002; Ramos 2013; Maticka-Tyndale and Drakich 1992; Eichler 2001; Hamilton 2003; see also CRSA 198518 (5) entire issue; Canadian Journal of Sociology 200126 (3) entire issue; Cahiers de Recherches Sociographique 392003 entire issue). However, neither historians nor sociologists have documented in detail how such substantive, theoretical and methodological specializations came to be institutionalized.

A helpful recent addition to the literature in the area is an article by Allyson Stokes and John McLevey (2016). Stokes and McLevey do not examine institutionalization, but they do describe shifts in the "macrolevel intellectual structure" of English-language Canadian sociology, 1966-2014. Drawing on "co-citation network analysis," they document changes to the "specialty structure" of the discipline. Their data show that from the mid-sixties to the mid-eighties the dominant specialties coalesced around John Porter's The Vertical Mosaic (1965) while, by 2015, the dominant specialties had largely changed and had coalesced around 
the work of Pierre Bourdieu. ${ }^{6} \mathrm{SI}$ is one of the specializations that appears throughout the five-decade span they analyse. Indeed, their findings re the SI specialty area accord closely with ours.

Some other studies that might be relevant to our purpose-e.g. historical-biographical treatments of figures such as Carl Dawson (Shore 1987; Helmes-Hayes 1994), Everett Hughes (Ostow 1984; HelmesHayes, ed. 1998; Low and Bowden 2016; Vienne 2016) Jean Burnet and Aileen Ross (Hoecker-Drysdale 1990, 1996) - do not say much about SI. Jennifer Platt's report on the "distinctiveness" of Canadian research methods documents a substantial surge in the use of "qualitative methods" during the eighties and nineties (2006: 213; Tables 2 and 3), but offers no comments regarding any link between this development and the growing popularity of SI.

\section{Approaches to the study of sociological theory}

Scholars have employed numerous strategies to describe and explain the origins, development, impact, etc. of sociological theories. Some analysts have focused on concepts. For example, Charles Page (1940) and Jan Pakulski and Malcolm Waters (1996) examined the concept of "class." Others have studied the contributions of individual theorists. For example, Stephen Lukes (1973) and Marcel Fournier (2007) have written major works about Emile Durkheim. Other researchers have described the development of theoretical paradigms, traditions, schools, etc (e.g. Friedrichs 1970; Wiley 1979; Bulmer 1984; Rosenau 1991; Wiggershaus 1994).

Our project most closely approximates the work of those who have examined the development of a "school" or "tradition" of theory. There are many such discussions of the SI tradition (e.g. Kuhn 1964; Meltzer, Petras and Reynolds 1975; Maines 1977, 2001; Rock 1979; Stryker 1980, 1981; Stryker and Vryan 2003; ; Denzin 1989; Fine 1990, 1993; Charon 1992; Lal 1995; Prus 1996; Abbott 1997; Dingwall 2001; Sandstrom, Martin and Fine 2001, 2010; Gusfield 2003; Reynolds and Herman-Kinney 2003; Vannini 2008; Hewitt and Shulman 2011). Unlike these scholars, however, we neither provide a description of various versions of SI nor attempt to assess their respective degrees of utility. Rather, we document the institutionalization of SI.

The notion of the institution is a core concept in sociology and discussions of the process of institutionalization abound in the literature.

6. The specialty areas Stokes and McLevey identify are not uniform in character. Some are substantive areas (ethnic relations), some are theoretical-methodological approaches (SI), and some are both (feminism, political economy). 
However, rather than puzzle over the relative utility of various theoretical conceptions of the terms "institution" and "institutionalization," we employ a set of operational definitions inspired by J. Graham Morgan (1966), Anthony Oberschall (1972: 207-8, 212-13; citing Fulcomer 1894; Tolman 1902; Bernard 1909), Nicholas Mullins (1973), Harry Hiller (1980, 1982) and, more recently, Rick Helmes-Hayes (2016). These investigators refer to numerous indicators/measures of institutionalization, but we use just three to document the institutionalization of SI: $1 /$ the appointment of SI and SI-accommodative scholars to permanent, full-time faculty positions; $2 /$ the regular and frequent appearance of SI-based scholarly research in prominent mainstream sociology venues (journals, textbooks); and 3/ the appearance of SI or SI-accommodative courses in university calendars (three or more courses constituting a "program"). We offer a detailed description of and rationale for our choice of measures in the section Methodology, Indices of institutionalization, below.

\section{Theoretical Touchpoints and Historical Context: The Process of INSTITUTIONALIZATION}

\section{Hiller on the institutionalization of sociology in Canada}

Hiller argues that sociology was institutionalized in Canada in four stages between 1900 and 1980: European transference (1900-1920), environmental adaptation (1920-1960), differentiation and specialization (the 1960s), and consolidation (the 1970s). By institutionalization, Hiller means what we mean: professors hired, research published, courses taught, departments established, etc. The framework he uses draws on four models: 1/ an "institutional" model which stresses the role of "university traditions, structures and rivalries" in "determining the shape of the sociological enterprise"; 2 / an "intradisciplinary" model which focuses on factors such as leadership, communication, and control of intellectual resources to explain "the rise and fall of dominant perspectives in sociology"; 3/ a "dependency" model according to which sociologists in a given national community choose (or are "forced") to "emulate" a style of sociology that originated in a foreign country; and 4/ an "ideological congruence" model according to which sociology uncritically reflects dominant "societal values and ideologies" (Hiller 1980). Hiller does not cobble these frameworks together into a formal model. Instead, he uses them on an ad hoc basis to describe and explain specific developments in the history of the discipline. 
Hiller claims that during the period of "European transfer" Englishlanguage Canadian scholars drew on a British "social analysis" conception of sociology (an example of "dependency") and argues that as late as 1920 sociology was institutionalized in only the most rudimentary way in the academy. Recent research challenges this claim - a form of social gospel-influenced sociology was well institutionalized in Canadian colleges and universities during this period (Helmes-Hayes 2016) - but for our purpose it does not matter. Neither "social analysis" nor social gospel-influenced sociology had an SI orientation or component.

During the subsequent phase of "environmental adaptation," 192060 , sociology grew slowly. The dependency model continued to be relevant; the British and American conceptions of sociology Englishlanguage scholars had drawn on during the first phase were joined by another American import; i.e. the so-called Chicago "school" of sociology, which took root at McGill University under the guidance of Carl Dawson. ${ }^{7}$ This created a space for SI to develop, for the McGill program was receptive to interpretive theory and fieldwork. However, other than at McGill, resistance to American sociology on the part of scholars in traditional humanities disciplines slowed the process by which American sociology in general and Chicago sociology in particular (including SI) institutionalized across the country (Hiller 1982: 40-63). Even more important was the slow expansion of the university system, which remained small until 1960 (268).

At that point, Canada's university system entered a fast-growth phase. Over the next decade, undergraduate and graduate enrolments grew rapidly to 385,000 and the faculty complement more than tripled to 22,000 (Hiller 1982: 21-3; see Table 3). Funding increased and was no longer a zero-sum game. This expansion opened the system to new intellectual practices because entrenched disciplines no longer had to defend their budgets or intellectual space. Sociologists took the opportunity to establish sociology as an independent discipline. Between 1960-1 and 1971-2, the number of universities offering sociology programs increased from 31 to 40 (Tomovic 1975: 20, Table 1 and 50, Table 4; see also Connor and Curtis 1970: 6, Table 1 and 78-9, Table 3) and the number of full-time sociology appointments in Canadian universities mushroomed from 61 to 548 (Hiller 1982: 23, Table 3). With growth came differentiation and specialization. By the early 1970s, sociology was a congeries of sub-disciplinary specialties, including SI.

7. Scholars disagree about whether or not Dawson tried to establish the McGill department on the Chicago model (Hall 1964: 116; Wilcox-Magill 1983; Nock 1988; Shore 1987: xiv). 
Hiller refers to the 1970 s as a period of "consolidation," during which gains made during the 1960 s, were solidified. The only developments germane to the institutionalization of SI were the continued growth of the discipline, an increase in doctoral-level training programs, and the rise of the Canadianization movement. The university system expanded to 65 (Canada, Statistics Canada, 1984: 3; Table 1) and enrolments increased to nearly 400,000 (Canada, Statistics Canada 1996: 136; Table A2). The number of sociology programs increased to 50 (Herman, Vallee and Carstens, eds. 1982: iii-iv) and the complement of sociology faculty grew to about 900 (Hiller 1982: 23; Table 3). SI benefited from expansion but, as an American import, faced resistance from those seeking to Canadianize the discipline.

We turn now to the work of Nicholas Mullins, who focuses more carefully than does Hiller on the intellectual and social aspects of the process by which nascent sociological theories become institutionalized.

\section{Mullins on theory group development}

In Mullins' scheme, theory development goes through four stages"normal," "network," "cluster," and "specialty" or "discipline" (1973: 17-32; summarized in Table 2.1, p. 28). Each has distinct social and intellectual features. Most important of them is the "communication structure" within nascent theory groups at each stage. Four kinds of relationships are significant: 1/ "communication" (serious talk about research); 2/ "co-authorship"; 3/ "apprenticeship" (teachers training students); and 4/ "colleagueship" (scholars working in the same department) (18-20).

In the normal stage, a theory group begins to emerge when an "intellectual leader" writes a key work that constitutes a conceptual breakthrough that differentiates the new approach from extant theories. This spawns "critical material" by members of the emerging group. Communication is loosely structured and group size is "indeterminate" (201, 25-9).

The network stage begins when someone produces a "program statement" capable of guiding the development of the perspective. Communication becomes more frequent and group members focus on one another as trusted assessors. Colleagues are recruited. The group reaches a consensus regarding the style and content of research. More research is published using the program statement as a guide. A "social organizational leader" emerges to organize a research and training center where apprenticeships develop. The network includes up to 40 persons $(21-2,26-9)$. 
The breakthrough stage for a new perspective is the cluster stage. Relationships among members become more formal and stable and communication becomes increasingly in-group oriented. "Clusters" of seven to twenty-five persons form at one or more major universities, comprising at least three researchers holding a Ph.D., one of whom is a "high producer," and several graduate students. In Mullins' terminology, these research and training centers constitute the first "institutionalization" of the approach, now concretized in formal colleague-colleague and teacher-student relations. Proponents produce more literature and focus increasingly on solving problems outlined in the program statement. Within-group theoretical connections are more prominent. Co-authorships appear, as do secondary materials such as textbooks (22-4, 26-9).

The specialty stage occurs as clusters break up. Students finish their degrees and begin teaching elsewhere. Some faculty members leave for positions at other universities. The connections among former members of clusters fade and the communication structure once again assumes the loose pattern of the normal stage, with twenty to 100 investigators now using the approach. Intellectual materials - journal articles, etc.-appear on a regular basis. Some secondary materials keep the perspective "pure," while others incorporate the theory into the mainstream. Final indicators of success are the establishment of teaching positions, training programs, and specialty journals (24-5, 26-9).

We draw on Mullins' model below. We do not, however, replicate his study in the Canadian context. Indeed, we do not need to document the process of "theory group development" per se. Theoretical and other developments in United States-based SI preceded the establishment and growth of SI in Canada during every period and in every particular and were imported across the border after a delay. Rather, we document the stages by which SI was institutionalized in Canada. We outline Mullins' model because we find that as SI institutionalized in Canada it exhibited some features of his approach.

One of the theory groups to which Mullins applies his model in the United States is SI (75-104). The origin of what is often referred to as "classical" SI is the work of George Herbert Mead, a philosophy professor at the University of Chicago. Mead's approach, outlined posthumously in Mind, Self and Society (1962 [1934]), constituted the basis for the normal stage of theory development which ended when he died in 1931. Mead influenced a number of Chicago sociologists who developed an interest in "social psychological" issues such as identity, the self, socialization, etc. (76-8). When Mead died, Blumer took over as the intellectual and social organizational leader of the group and the net- 
work stage (1931-45) began. In 1938, Blumer published SI's program statement, "Social Psychology," in which he coined the term "symbolic interactionism" and outlined his version of the approach. Blumer's framing established SI as a viable theoretical approach in social psychology (Mullins 1973: 80; 105-28). As well, there were enough faculty members and students to maintain a research center (79-80). The cluster stage (1945-1952) began after World War II. Chicago became the major research and training center for SI (83; Table 4-2, 84-8) and the perspective began to spread. By the 1950s, clusters had formed at Iowa and Minnesota and there were interactionists at about two dozen universities across the US $(83,88-9)$. However, Blumer failed to develop a viable method for SI (81) and other interactionists stepped into the fray, touting their own versions of the theory and offering suggestions about how to undertake empirical research (89-90; see also Abbott and Gaziano 1995). The specialty stage began when Blumer moved to Berkley in 1952. After he left, the Chicago core SI faculty cluster dissolved and no new students joined (92). Everett Hughes, Anselm Strauss and others remained as practitioners of SI-friendly sociology, but none was a classical Blumerian.

At the same time, in a consequential development at Harvard, Talcott Parsons reframed his approach so that it focussed more on macrosociological aspects of society (e.g. 1951). This created an opening for SI to dominate the study of individual and collective behavior (Mullins 1973: 96). The two perspectives, functionalism and SI, came to comprise the core of American sociology (96). Concurrently, however, other interpretive approaches such as ethnomethodology and phenomenology emerged as competitors to SI and critical materials appeared that highlighted SI's theoretical and methodological weaknesses (183-92). The result? By the early 1970s, Mullins says, SI's status as a "changemaker," a "general orientation for sociology," and "the loyal opposition to structural functionalism" had "come to an end." Scholars continued to do SI-flavored research, but the perspective had become "intellectually diffuse" and other theoretical approaches were squabbling over its territory and problem set (97-8). ${ }^{8}$

Taken together, Hiller's framework and Mullins' model provide tools that shed light on the process by which SI institutionalized in Canada.

8. Fine (1993) argues that SI retained its stature and viability into the $1980 \mathrm{~s}$. We discuss Fine's claims below. 


\section{Methodology}

\section{Indices of institutionalization}

We use three indices of institutionalization.

1. The appointment of SI or SI-accommodative scholars to permanent, full-time faculty positions: This is a bedrock indicator of the establishment and spread of disciplines and sub-disciplinary specializations alike and has been used in numerous studies (e.g. Shils 1970; Mullins 1973; Tomovic 1975; Wiley 1979; Hiller 1980; Helmes-Hayes 2016). The appointment of a faculty member becomes a steppingstone to further development. Courses are taught. Research is published. Graduate students are attracted and trained. Institutionalization as effect becomes institutionalization as cause.

2. The regular and frequent appearance of SI-based scholarly research in prominent mainstream Canadian sociology venues: Specifically: the publication of SI-based (or SI-“flavoured") articles in the Canadian Journal of Economics and Political Science (CJEPS), the Canadian Review of Sociology and Anthropology (CRSA) and the Canadian Journal of Sociology (CJS), the appearance of SI-based chapters in introductory sociology and Canadian Studies readers/textbooks, the coverage of SI as a standard theoretical approach in introductory sociology textbooks/readers, and the production of SI-only or SI-accommodative general introductory sociology textbooks and sub-disciplinary textbooks (e.g. on deviance).

3. The establishment of SI-accommodative/friendly programs: The establishment of a "program"; i.e. a complement of three or more SI or SI-accommodative faculty, multiple SI-compatible courses in which the SI theoretical orientation and fieldwork/ ethnography are taught either as one of a number of interpretive theoretical approaches or solely, and, for graduate students, the possibility of undertaking an SI-based MA or PhD thesis, is another indicator that an approach has been institutionalized. 


\section{Research techniques}

\section{Identification of SI community members}

Mullins used a broad definition of interactionism but restricted group membership to those interactionists employed at major American universities who had published two or more articles in major journals (1973: 317). We, too, used a broad definition of SI, but did not employ equally restrictive criteria regarding either institutional affiliation (major universities only) or venues of publication (major journals only). The Canadian sociological community is too small to allow the use of such restrictive criteria.

We are interested in the institutionalization of SI as indicated by the appointment of faculty to full-time teaching positions at Canadian universities. Therefore, we defined core SI group members using two criteria: $1 /$ they had a full-time, permanent appointment at a Canadian university 9 ; and 2/ they used an interactionist perspective in their research. As we operationalized the term, "being SI" meant that a faculty member drew in a positive way on recognized traditions of SI theory (e.g. Blumer, Manford Kuhn, Carl Couch, Gregory Stone, Erving Goffman, Howie Becker, Anselm Strauss) and used fieldwork methods (direct observation - participant or otherwise - and non-fixed choice interviews).$^{10}$ We labeled a faculty member "SI-accommodative" if s/he seemed willing to accommodate SI-style work as indicated by the use of fieldwork methods (observation and open-ended interviews) and the application of some variety of non-SI interpretive theory (e.g. ethnomethodology) in her/his own research.

For reviewers, this issue; i.e. how we operationalized "being SI" or "being SI-friendly" (as we termed it in the original version of this essay), was by far the most contentious aspect of our paper. Indeed, we were criticised for even trying to enumerate the SI community. One reviewer referred to it as a "problematic counting exercise" and argued that instead of trying to "pigeonhole" people as SI or SI-friendly we should do a "qualitative analysis" of SI "work." We respectfully disagree and here

9. If someone was first appointed to a non-tenure-stream position, but eventually hired at the same university to a full-time, permanent position, we used the date of their initial appointment as their start date. We did not count "adjunct" faculty or sociologists teaching in "other departments, schools or institutes" of the university sociology department in question. We made one exception to the rule that the faculty member had to have a full-time, permanent position: Cheryl Albas. She is a core member of the SI community who has taught at Manitoba as a sessional since the 1970s.

10. We understand that not all those who do fieldwork are sympathetic to SI. 
provide: i/ a defence of our decision to enumerate the SI community; ii/ an explanation of why our "pigeonholing" of interactionists, SI publications, etc is, in fact, one measure of SI's influence during the period; and, iii/ a justification for our operationalization of the terms "symbolic interactionist" and "SI-accommodative."

Sociology is, or should be, as far as possible, an empirical discipline. When a researcher wants to make a factual claim about "what happened," in this case the spread of SI as a perspective, he/she should be able to point to data that demonstrate that the perspective was institutionalized - when, where, by whom, in what ways. Indeed, we would argue that data about institutionalization is the first and most basic indicator of "influence": how many people taught it, used it in their research, etc. In this paper we report data we gathered/created ${ }^{11}$ to document the institutional and intellectual footprint of SI in Canada. We counted interactionists, we counted SI publications, etc. Mullins counted in his 1973 book; he counted people, co-publications, etc. to show how theoretical perspectives develop in a network pattern. Diana Crane counted in her famous studies of the editorial review process and the influence of "invisible colleges" (Crane 1967, 1972). Stokes and McLevey (2016) counted in their efforts to map co-citation networks in English-language Canadian sociology. We could multiply the examples. The point is that none of these investigators would apologize for counting. Neither do we. We want to make the empirical claim that SI has spread in Canada and that - in that respect at least - its influence has grown. In order to feel comfortable in making that claim, we made some decision rules (outlined below) about who counted as SI, what counted as an SI-influenced journal article, etc.

That said, we appreciate that it is important to examine the literature of Canadian sociology to assess the nature and extent of SI's influence or impact - in one reviewer's words, to assess "what issues SI helped Canadian sociologists address" and how "SI as a paradigm ... contributed to our knowledge of Canadian phenomena." 12 In our view, documenting institutionalization and reviewing the literature are complementary ways of assessing influence. Indeed, we would insist that whatever impact or influence SI had on the literature (new issues examined, old issues exam-

11. Our use of the terms "gathered /created" is intentional (see below).

12. There are, of course, different ways to talk about the "influence" or "impact" of books and/or articles. Two Canadian studies that assess different aspects of influence are Nock (2001), who documents the most cited - and (perhaps) therefore, most impactful - Canadian books of the period 1975-1987, and Hiller and Langlois (2001), who report the "most important" books and articles of the twentieth century. 
ined in new ways), none of it would have happened unless SI appointments, courses and programs had been put into place. Further, we would claim that our study of institutionalization does document one measure of SI's influence on the literature-its presence in the form of journal articles and textbooks. A more detailed analysis of themes, topics, etc would be a worthwhile next step, and would surely reveal SI's influence on other theoretical perspectives such as feminism (see Stokes and McLevey 2016: 192, 196). But any sort of "qualitative analysis" of SI "work" would run into exactly the same problems we ran into here. How do you decide what constitutes "SI work"? What would count as an indication of "SI's influence"? How would you differentiate between SI's influence and the influence of other interpretive sociologies? Et cetera.

So we reiterate our purpose: to document the process by which an academic specialization, in this case SI, became institutionalized at a national level. As our reviewers noted, we could likewise analyse other sociological approaches/specializations-feminism, Marxism, political economy, Canadian Studies - that established equally substantial footholds in Canadian academia during the period. Such analyses would reveal that each of these perspectives went through processes and growing pains that were both similar to and different from SI. One crucial factor that has an impact on all hopeful specialties is the relatively modest size of the Canadian national sociological community and, even more importantly, the small size of most departments. Both factors make it difficult to establish and maintain second-tier and/or emergent specializations, especially as stand-alone entities. There simply are not enough faculty positions available. Some approaches are better able to survive and prosper in these circumstances, in part because they are unitary within (e.g. the new radical political economy of the seventies and eighties). But other specializations/approaches are riven internally on theoretical and/or political grounds - e.g. feminism and SI. That said, some new approaches retain a degree of momentum once established, despite the fact they are internally divided, because the issues with which they deal remain unresolved - feminism - or because they are able to draw support from scholars in closely related niche or specialty areas. SI for example, drew support from theorists in other interpretive traditions such as phenomenology. Still other approaches achieve their goals and are subsumed. In essence, they make themselves "unnecessary" as standalone areas-SI and Canadian Studies are good examples. But this sort of comparative work, while worthwhile, is beyond the scope of our analysis here.

Let us turn to the most contentious of the issues raised by reviewers: the problem of whom we labelled SI and SI-accommodative. We were 
well aware, before reviewers raised the question, that it is impossible to develop a definition of "SI" and a related definition of who is a "symbolic interactionist" or "SI-accommodative" that all SI practitioners would accept. One review of our paper, written by a classical Blumerian, simply asserted that if you are not a Blumerian then you are not SI. By his/ her rendering, because we extended the label SI beyond Blumerian SI, our entire paper was a "fiction." But surely this will not do. By such an account, a wide range of scholars who would themselves claim the SI label in some way and/or who would be seen by others as contributing to SI would not count as members of the community: Fine, Kuhn, Glaser, Strauss, Couch, Stone, Hughes, Goffman, and Joe Gusfield among them. ${ }^{13}$ On the other side of this debate, interactionist Philip Vannini has argued that such essentialist definitions of SI are nonsense. He claims that American symbolic interactionists read only English and, thus, do not appreciate that there are several forms of interactionism around the world, some of which have little or no connection to the Mead-Blumer tradition. In Vannini's view, one can speak of SI only if one "abandons any notions of 'core essence' or 'purity' and 'orthodoxy"' (emphasis added). There is, he writes, "no one fixed meaning of SI"; the meaning of the term has changed and will change over time as it is negotiated by those "whose interaction constitutes its meaning" (2008: 11-12; see also Plummer 1996: 225).

Faced with this contentious situation, we decided not to try to solve the problem of who was or was not a "real" or "true" symbolic interactionist using theoretical criteria. Instead, like Mullins, we adopted a simple and broadly inclusive definition. We acknowledge that our definitions of SI and SI-accommodative have theoretical implications and are open to dispute, and we recognize that we have constructed a particular version of Canada's SI community by using such rules. However, we see no other way to proceed if we wish to study empirically the institutionalization of SI as a theoretical perspective at a national level. We would stress as well that it is important to enumerate not just core members of the community, but those who we referred to as "accommodative." It is only with the intellectual openness and support of non-core scholars that a niche theoretical specialization such as SI can become institutionalized and influential in a small national sociological community such as Canada where relatively few faculty positions are available to nonmainstream scholars.

13. Mullins lists about 100 people as "important symbolic interactionists." His list includes Becker, Glaser, Goffman, Hughes, Kuhn, and Strauss (1973; 84-8; Table 4-2), all of whom would be regarded by a Blumerian purist as "not SI." 
To flesh out this last claim, let's take two examples; i.e. Frank Jones and Dorothy Smith, who reviewers claimed we had incorrectly categorized as "SI-friendly" in the original version of this paper. Jones has a stellar reputation as a quantitative researcher who studied macrosociological phenomena. However, early in his career he did fieldwork on the socialization of infantrymen (1961). We do not claim he "did SI." Nor do we claim, as one reviewer suggested, that Jones "wrote or interpreted his work though the SI lens" or regarded his work as "a contribution to SI." However, his fieldwork-based paper on infantry recruits involved understanding the process of becoming an infantryman from the point of view of the individual forging a new identity. This suggests he would be tolerant, perhaps even supportive, of a student who wanted to do a similar project using SI. Dorothy Smith's case is similar. Her work is rooted in Marxism, phenomenology, pragmatism, and feminism (1987). She advocates the use of fieldwork: institutional ethnography (2005). There is no doubt she would be critical of the analytical/theoretical limits of some kinds of SI. We do not claim she "did SI" or saw herself as "contributing to" SI. We do claim that she would be happier to see a student use SI and do fieldwork than use functionalism and gather data via a fixed-choice questionnaire. In that sense, she would be SI-accommodative (1987). By our rendering, then, Jones and Smith would be what we originally called "SI-friendly" and what we now refer to as "SI-accommodative." We intend this change in labels to highlight the idea that we are aware that there were and are people who would exhibit different degrees of "friendliness" to SI. At a bare minimum, they would tolerate/ support such work by graduate students in the department.

With this extended explanation and justification of our decision rules in place, we move to a description of the research techniques we used to identify members of the SI community.

For the period 1922-1959: i/ We examined university calendars and secondary literature dealing with the history of Canadian sociology to compile a basic list of interactionists. We then reviewed the "sources cited" in their published research and checked the published research of any Canadian scholars they cited to see if it was SI-oriented. If so, we added them to our list. ii/ We checked the articles published in the discipline's major journal, the CJEPS, 1935-59, and identified those with an SI orientation or who appeared to be SI-accommodative.

For the period 1960-79: i/ We reviewed four CSAA-sponsored directories of sociology programs at Canadian universities (Connor 1968; Connor and Curtis 1970; Herman and Carstens eds. 1978; Herman, Vallee and Carstens eds. 1982) to identify sociologists whose substantive or theoretical specializations/interests indicated they were interactionists 
or SI-accommodative/friendly. ii/ We examined articles published in the CJEPS, 1960-64, the CRSA, 1964-79, and the CJS, 1975-79. iii/ We reviewed introductory sociology and Canadian studies textbooks. iv/ We conducted exploratory interviews during which we asked our interviewees to suggest names of those they regarded as members of the SI community in Canada, 1960-79. In some cases, we were able to contact the persons so-named and ask them to identify themselves as SI, SI-friendly, or SI-accommodative. We could not trace some of these scholars. In such cases, we used their published research to make a determination.

It was relatively easy to identify the core members of the SI community for the period. Most had trained at Chicago and we identified them via interviews and secondary sources. Interestingly, however, when we read their work, we discovered that even the sociologists we knew from other sources to be core interactionists (e.g., Aileen Ross, Jean Burnet, Rex Lucas) did not in their published research locate themselves in the SI tradition. They drew on interactionist literature - Cooley, Thomas, Mead, etc.- - and undertook SI-style fieldwork. However, they did little or no "theorizing" and neither referred to themselves as interactionists nor described their work as emanating from within SI. Robert Dingwall argues on this count that the same thing happened in the US. "The generation after Blumer shows only a patchy adoption of the term.... [M] ost of those who might now be anachronistically classified as symbolic interactionists would simply have said that they were doing sociology" (2001: 238).

We faced a similar problem in our analysis of the second period, 1960-79. It was sometimes difficult to distinguish between core interactionists and those who were SI-accommodative. A review of: i/ articles published in the CJEPS, the CRSA, and the CJS; and ii/ the contents of introductory sociology and Canadian Studies textbooks allowed us to identify several new members of the community. ${ }^{14}$ A review of two CSAA-sponsored directories of sociologists and anthropologists in Canada (Herman and Carstens eds.1978; Herman, Vallee and Carstens eds. 1982) allowed us to supplement our lists - but we had to be careful about drawing too-firm conclusions from the listings. We included as SI-accommodative those who referred to their areas of specialization as "micro theory," "interpretive theory" (or any specific variant of interpretive theory such as "phenomenology" or "ethnomethodology"), "field work," or "qualitative methods."

One development that helped beginning in the 1970s was that a degree of us-versus-them sectarian self-labelling began to occur within the SI camp. Some interactionists began to announce in their published work

14. See the discussion re Identification of SI literature, below. 
that they intended it to contribute to a body of SI scholarship rooted in the work of, e.g., Herbert Blumer. This self-labelling was a boon to us, but a sign of difficulties within the community, for it illustrated the beginnings of a boundary dispute over who controlled the SI label and, therefore, who would count as SI or SI-accommodative. During the period, the number of challengers to classical SI grew: Kuhn (Kuhn and McPartland 1956), Stone (Stone and Farberman eds. 1970), Couch (1968, Couch and Hintz eds. 1975; see Katovich, Miller and Stewart 2003), Howard Becker (1963, 1970), Barney Glaser and Anselm Strauss (1967)—even Hughes (Helmes-Hayes 1998).

\section{Identification of SI Literature}

We used two measures to indicate the degree to which SI-rooted research had become accepted/ institutionalized in Canada: 1/ the publication of SI-based articles in the CJEPS, the CJS and the CRSA, the discipline's three general journals; and 2/ the appearance of SI-based materials in Canadian undergraduate sociology/Canadian Studies textbooks. ${ }^{15}$ In all cases, we coded an article or chapter as SI-based if: i/ it drew in a positive way on standard interpretive sociology theoretical sources, especially SI theoretical sources (e.g. Mead, Thomas, Cooley, Blumer) and/or; ii/ it involved "fieldwork," which we operationalized as direct observation (participant or otherwise) or the use of non-fixed-choice interviews. ${ }^{16}$

To determine the profile of SI and SI-style research, we surveyed the English-language articles published in the CJEPS, 1935-63, the CRSA, 1964-1979, and the CJS, 1975-79. We reviewed the first number of each volume (vol.1, no. 1; vol. 2, no. 1; etc) of the CJEPS and the CRSA and every number of every issue of the $C J S$ for the period- 158 articles from the CJEPS, 67 from the CRSA and 73 from the CJS; i.e. a total of 298 articles.

In addition, we surveyed Canadian undergraduate sociology and Canadian Society textbooks/readers (both general "intro" books and texts in specialty areas such as deviance and social problems) published

15. We include Canadian Society readers/textbooks in this analysis because, as Hiller and di Luzio point out, during this period introductory sociology and Canadian Studies books were often "at least partially interchangeable" (2001: 501; note to Table 3).

16. Stokes and McLevey used a different research technique to identify SI as one of the "specialty areas" in the overall "network" of Canadian sociology. Nonetheless, they had to use a similar technique; i.e. looking at the titles, abstracts and bibliographies of co-cited journal articles, to label individual publications as SI and, therefore, assign a label to the specialty area (2016: 182). 
1960-1979, on the grounds that such volumes are indicators of the general state of a discipline's conventional wisdom that identify standard approaches, theoretical and methodological alike. As an indicator of the situation at the end of our first stage, 1922-1959, we "cheated" and used the first Canadian sociology reader, Canadian Society (Blishen et al, eds. 1961), on the grounds that the editors compiled it beginning in 1957 and intended it to be representative of Canadian sociological research of the time (Helmes-Hayes 2010: 111-12). Finally, we reviewed the nineteen general introductory sociology texts/readers listed in Hiller and DiLuzio's article, "Text and context: Another 'chapter' in the evolution of sociology in Canada" (2001).

\section{Identification of SI-Accommodative Programs}

We operationalized the notion of an SI program as follows; a department in which there was: $i$ / some combination of three symbolic interactionists/ SI-accommodative faculty, and ii/ multiple SI or SI-compatible undergraduate or graduate courses, particularly interpretive theory and qualitative methods or fieldwork courses - so that graduate students could undertake thesis research employing SI theory and methods. In order to identify SI or SI-compatible courses we reviewed university calendars (graduate and undergraduate) looking for theory, methods, and substantive courses which, in the case of theory, used the term "SI" in either the course description or title or, in the case of methods, referred to "fieldwork," "ethnography," "observation" or "participant observation" in either the course description or title.

\section{FindingS}

We report our findings in terms of two time periods: 1922-1959 and 1960-79. Each has distinctive features that indicate SI had reached a particular stage of institutionalization. We chose 1922 as the start date because that is when McGill hired Dawson to run its program in social service and teach sociology. Though Dawson was not an interactionist per se, his appointment was the first step in the institutionalization of SI in Canada for he was SI-friendly. We chose 1959-60 as the (somewhat arbitrary) dividing line between the two stages because around this time the university system entered a rapid-growth phase. This expansion of the system as a whole created the institutional space and bureaucratic logic within which interactionists and other niche specialists were able to establish an increased presence in sociology departments. We chose 1979 as the end of the second period for three reasons. i/ By this time 
SI was fully integrated into the literature (journals, textbooks). ii/ Most departments had appointed one or more SI or SI-accommodative faculty members. iii/ SI was no longer viewed as a challenger to mainstream sociological practice; it had itself become part of the mainstreamthough with a second-tier profile. In the 1980s, a different dynamic arose. The processes of fragmentation, expansion, incorporation, and adoption described by Fine (1993) kicked in (see also Michalski 2016; Stokes and McLevey 2016).

\section{2-1959: On a mission: fanning the flame}

The slow and belated development of sociology in general and SI in particular must be understood in light of the modest size and traditional culture of the university system of the time. In 1920, Canada had twentytwo universities (Canada, Dominion Bureau of Statistics 1921: 150-1) and combined they employed only 2,200 full-time teaching staff. Enrolment was just 23,000. ${ }^{17}$ Even in the mid-1920s, McGill's enrolment was just 3,000 (Frost 1984: 127). However, over the next three decades, the system grew substantially. By 1960, Canada had thirty-eight universities (Reid 1961: 243) that employed about 8000 full-time professors and enrolled 114,000 students. ${ }^{18}$ Curriculum shifted away from traditional humanities subjects - philosophy, languages, theology — toward modern, scientific ones.

Sociology was part of the new curriculum and McGill was in the forefront of its development. Beginning in 1922 with Dawson's appointment and for over two decades thereafter, human ecology held centre stage in McGill's teaching and research program. In the early years, Dawson used the Park and Burgess textbook in multiple courses, but in 1929 co-authored his own Chicago-inspired introductory textbook which went into three editions (Dawson and Gettys 1929, 1935, 1948). While all three editions were rooted in human ecology, each contained an extensive discussion of "social psychology," including interactionist-type themes. In the first two editions, Mead, Cooley and Thomas were among

17.For 1920 data re 1/ faculty complement and 2/ undergraduate enrolment, respectively, see Leacy, ed. (1983), Series W475-485: full-time university teachers, Canada and by province, selected years, 1920 to 1975; and 2/ Series W439-455: full-time university undergraduate enrolment, by field of specialization and sex, Canada, selected years, 1861 to 1975.

18. For 1960 data re 1 / faculty complement and 2/ student enrolment, see Leacy, ed. (1983) Series W475-485: full-time university teachers, Canada and by province, selected years, 1920 to 1975; and 2/ Series W340-438: Full-time undergraduate enrolment, by sex, Canada and by provinces, selected years, 1920 to 1975. 
the most-cited authors in the book. By the third edition, Blumer's work was sixth most-cited, ahead of Mead, Thomas and Cooley and behind only Park, Burgess and three functionalists. This mixture of sourcesecological, functionalist, interactionist-reflected Dawson's efforts to develop a comprehensive theoretical perspective (Helmes-Hayes 1994; see especially 466, Table 1). Another related interactionist feature of the program was Dawson's encouragement of fieldwork. David Solomon, a student at McGill in the late 1930s (and later a McGill faculty member) recalls there was a premium placed on data gathering, including fieldwork (interviews, in situ observation) for all undergraduate and graduate course essays (n.d.: 4). ${ }^{19}$ This fostered an environment supportive of SI. In 1927, in a move that was especially consequential, Dawson hired Everett Hughes, another Chicago PhD and student of Park, to help him build the program.

Hughes played the decisive role in building an environment supportive of fieldwork and SI-style theory at McGill. From 1927 to 1938, he taught courses that bore the imprint of ecological, interactionist, and other theoretical sensibilities ${ }^{20}$, promoted fieldwork, encouraged an interpretive approach to sociological research, and led by example. His own research was rooted in human ecology and a type of interactionism based in the writings of Cooley, Thomas, and Georg Simmel (HelmesHayes 1998; Hughes 1971 [1960]: 497-8). Indeed, he did several studies based in part on fieldwork and interpretive/interactionist theory leading up to the publication of French Canada in Transition (1943). These activities made interactionist/interpretive sociology central to the program. That said, Hughes never referred to himself as a symbolic interactionist and did not locate his work in the context of interactionist theory (Helmes-Hayes 1998: 650). ${ }^{21}$

19. Dawson's course, "Sociology 2: The Community," initially offered in 1922 , was probably the first to provide fieldwork training. According to the Calendar description students would study the city by means of "maps, case studies and concrete investigations" (McGUC 1922-23: 412). He probably taught fieldwork in his graduate course, "Social Research: Canadian Problems," as well (offered each year 1923-28). Beginning in 1928, Hughes likely offered fieldwork instruction in the social research course he taught ( $M c G U C$ 1929-30: 490). Other faculty likely continued the practice after Hughes left for Chicago (see, e.g., McGUC 1948-49: 843). However, it is not possible to say definitively from Calendar entries.

20. Hughes taught "Social Institutions" and "Sociology of the Child," both of which used interpretive/constructionist theory throughout (Bayley course notes, $c a$ 1934-35; from the files of R. Helmes-Hayes).

21. Mullins lists Hughes among those he regards as "important symbolic interactionists" (1973: 84-8; Table 4-2). 
When Hughes left McGill to return to Chicago, he retained close connections with many French- and English-language Canadian sociologists and through them had a major impact on the discipline north of the border. Largely in consequence of his influence, an active pipeline developed between McGill and the Windy City. Indeed, nine of the eleven full-time faculty hired at McGill before 1960 were Chicago graduates and several McGill MAs went to Chicago for the PhD. ${ }^{22} \mathrm{As}$ a result, throughout the period 1922-59, McGill was the centre of SI-type teaching and research in Canada. Faculty came and went but by 1960 there were four-all Chicago PhD graduates: Aileen Ross, Fred Elkin, William Westley, and David Solomon. All had earned their doctorates during the period when Blumer and others were packaging SI and all were either self-proclaimed interactionists (Ross) or SI-accommodative (Elkin, Westley, Solomon). ${ }^{23}$ Archival evidence indicates that by the late 1940s Aileen Ross had incorporated a substantial discussion of SI into her course on the sociology of the child. One of the questions on the final examination read: "How does the symbolic interaction school describe the rise of the 'self'? State some important respects in which this theory differs from other theories with which you are familiar." (MUA, McGill University Faculty of Arts and Science Second, Third and Fourth Years Examination Papers (1949), Sociology 42b, 20 April 1949).

The only other place SI had a profile was Toronto. Beginning in 1945 with the hiring of Jean Burnet (who left in 1966), Toronto developed a group of SI-accommodative/friendly faculty that included, in addition to Burnet, Leo Zakuta (1952-84), Jim Giffen (1953-84) and Oswald Hall (1956-75) (Helmes-Hayes, ed. 1988: Chapter 3 and Appendix A). ${ }^{24}$ Even here, Hughes' reach was long. Both Burnet and Zakuta mentioned him as influential in their graduate training (Burnet interview, 1995; Zakuta interview, 1995) and Hughes supervised Hall's PhD dissertation.

22. McGill MAs who went to Chicago for the PhD include Ross, Hall, Zakuta, Burnet, Solomon, Rex Lucas, and Dan Lortie.

23. Re: Solomon's attachments to the Chicago tradition in general and Hughes in particular, see Solomon (1968: 3-5; nd: 17). Mullins includes Solomon on his list of "important symbolic interactionists" (1973: 84-8; Table 4-2). Re Westley's connections to SI, see Leznoff and Westley (1956). Though not an interactionist per se, Elkin taught the sociology of the child which emphasized "theories of human nature" and "socialization" as early as 1956-7 (McGUC 1956-7: 1157). Forrest Laviolette, who taught at McGill 1940-49, had a Chicago $\mathrm{PhD}$ and trained with Hughes and Blumer. Oswald Hall did his $\mathrm{PhD}$ with Hughes and worked in a Hughesian style in the area of occupations and professions.

24. Aileen Ross taught at Toronto (1942-5) before going to McGill (HelmesHayes, ed. 1988: Chapter 3 and Appendix). 
Currently, the conventional wisdom is that only at McGill did Chicago sociology (including SI) gain a strong foothold. At Toronto, so the argument goes, Clark and Innis combined forces to prevent it from developing. However, the presence of three or four SI-accommodative/friendly faculty throughout most of the 1950s-Burnet, Zakuta, Giffen and Hall - indicates otherwise. American-style sociology, and certainly an environment somewhat supportive of SI, existed at Toronto-despite the efforts of Innis and Clark. Between 1945 and 1959 Toronto faculty produced a number of fieldwork-based, SI-influenced studies (e.g. Giffen 2004 [1946]; Burnet, 1947, 1951; Hall 1946, 1948, 1949). Until the mid1950s, it appears there were only two SI-accommodative sociologists based at Canadian universities other than McGill and Toronto; i.e., Coral Topping, who taught at UBC 1929-54 and at United College 1954-7 (re Topping, see Helmes-Hayes 2014) and Kaspar Naegele, who taught at UNB 1946-54 and at UBC until 1965. However, between 1955 and 1959 four Canadian universities hired SI or SI-accommodative faculty: Acadia (Rex Lucas), McMaster (Frank Jones), Saskatchewan (Henry Cooperstock), and UBC (Bernard Blishen).

TABLE 1: SI CORE AND SI-ACCOMMODATIVE FACULTY, 1922-1959, LISTED ALPHABETICALLY

By 1959, then, SI was institutionalized somewhere between the network and cluster stages of Mullins' model. Both McGill and Toronto had three or more SI or SI-supportive faculty who interacted locally in a group-sustaining way to support the perspective. At McGill the department's calendar entry made no mention of SI, but it had long offered SI-compatible/inclusive courses and offered courses which appeared to 
include instruction in fieldwork methods (e.g. McGUC 1922-23: 412; McGUC 1929-30: 490; McGUC 1939-40: 479; McGUC 1948-49: 843; McGUC 1950-1: 2711). The first course to mention "participant observation" appeared in 1953-4 (McGUC 1953-54: 1152) and the first to use the term "field research" appeared in 1954-5 (McGUC 1954-55: 1152; see Table 3). Long before this, however, members of the faculty did SI-style research and supervised MA theses based at least in part on fieldwork and interactionist theory. These are the criteria Mullins specifies as central to a theoretical approach as it enters the cluster stage. Other developments indicative of reaching the cluster stage came slowly. Early in the period Hughes acted as social and organizational leader, but he left for Chicago in 1938, and had no obvious successor. Indeed, though McGill had the faculty and graduate student numbers to constitute a cluster, until 1960-61 it lacked a $\mathrm{PhD}$ program. MA graduates attended Chicago for their doctoral studies. Moreover, the faculty cohort did not co-publish. As well, even those who were core interactionists did empirical research about substantive issues in the style of Hughes rather than focusing on the theoretical problems set out in Blumer's program statement. ${ }^{25}$

These developments were good news for Canada's interactionists, but the national sociological community remained small-approximately sixty scholars - and it was, thus, impossible for a niche perspective such as SI to gain much prominence. New appointments went to generalists, expected to teach introductory sociology and other standard substantive areas: immigration and settlement, ethnicity, family, religion, work, and the like. Functionalism was the dominant theoretical perspective in both Canada and the United States and, in Canada at least, historical methods and survey research were the primary methodological orientations.

During this period, the only Canadian social science journal in which sociologists could publish was the CJEPS, founded 1935. Our review of the articles in the CJEPS (1935-1959) revealed that SItype work had only a spectral presence there. Of the 158 articles we reviewed, only four (Hall 1946; Naegele 1951, 1956; and Westley 1957) could be classified as SI in orientation.

25. Ross' PhD dissertation was a partly fieldwork-based study of the "invasion" of the English-dominated Eastern Townships of Quebec by FrenchCanadians (1943, 1954a). As well, she carried out a fieldwork-based study of philanthropy in Montreal (1952, 1954b). Solomon undertook fieldworkbased studies of the Canadian military (1954) and Hall studied the informal organization of the medical profession (1946, 1948, 1949). 
The situation was the same in terms of textbooks. No Canadabased interactionist published an SI reader or textbook during the period and mainstream Canadian sociology was slow to accept SIstyle work. In 1961, just after the close of this first stage, Bernard Blishen, Frank Jones, Kaspar Naegele and John Porter co-edited Canada's first sociology reader, Canadian Society: Sociological Perspectives. Though not a textbook, Canadian Society showcased what the editors regarded as a set of $36 \mathrm{key}$ empirical studies of Canadian society. Fifteen chapters were rooted in whole or in part in fieldwork methods, including interviews and direct observation. However, the index did not mention Mead, Blumer or SI and just three SI or SIaccommodative scholars (Ross 1943; Hughes 1943; Solomon 1954) had chapters in the book. ${ }^{26}$ The book contained a few other chapters (e.g. Seeley, Sim and Loosely 1956; Cooperstock 1961) based on fieldwork and rooted in whole or in part in interpretive social psychological theory, but overall SI had only a marginal presence. Stokes and McLevey claim that during this period, indeed prior to 1975, all the specialties in Canada were sparse and disconnected (2016: 186 n. 8).

\section{0-1979: Mission accomplished: stepping into the light}

Everything changed during the period 1960-79. The SI community expanded substantially, SI became an accepted specialization, and its presence in the literature grew markedly. Indeed, Stokes and McLevey's data indicate that by 1984 SI was "major specialty area" in the discipline (2016: 186, 188). These developments did not occur solely or even primarily as the consequence of any special merits SI possessed as an approach. Rather, SI became increasingly institutionalized because interactionists, like other sub-disciplinary specialists, took advantage of openings created by stunning system-wide growth in Canada's post-secondary educational system to expand and solidify their base of operations. As Table 1 demonstrates, in 1959 the core SI community numbered only six and SI-accommodative faculty only twelve. Table 2 shows that twenty years later, the community numbered about ninety, nearly three dozen of whom were core members. This constitutes substantial growth. However, in relative terms, the core had no more than a very modest presence in the national sociological community of about 900 . This is one of the rea-

26. We indicate the original date of publication for each chapter. 
sons we documented the appointment of SI-accommodative faculty. Departments were small, typically less than twenty faculty. They might hire one SI specialist. As noted above, SI could gain traction in such an environment only if other SI-supportive or SI-accommodative faculty were hired or already in place. Such colleagues might teach courses with an SI component and would be available to act as resources for graduate students wanting to do SI-based theses. Only in this way could SI build a substantial profile. And this is what the data from Stokes and McLevey indicate. SI's influence by the 1990s came through its links to other clusters: "crime," "ethnomethodology and phenomenology" and, via Goffman, "German microsociology" and "socialization" (2016: 188).

McGill retained its status as the centre of SI through the 1960s and into the 1970s. Shaffir notes that during this two-decade span the McGill department had the largest group of "Chicago" sociologists in Canada. At various times, Ross, Westley, Solomon, Malcolm Spector, William Hanigsberg and Prudence Rains were on staff-a minimum of five in any year. This allowed the department to be supportive of interactionist theory and field research throughout the period. As Shaffir put it: "There were a number of people at McGill ... doing ethnographic research who may not have called themselves 'symbolic interactionists,' but who obviously subscribed to the philosophy underlining that tradition" (Shaffir interview 2010; see also Shaffir interview 2002). Indeed, McGill developed the first SI-based $\mathrm{PhD}$ specialization in Canada and, in 1972, Shaffir became its first graduate (Shaffir interview, 2002, 2010). In honour of the occasion, the department made a special event out of his dissertation defence; Howie Becker served as the external examiner and Everett and Helen Hughes attended (Shaffir interview, 2002). However, by the turn of the decade, only three core SI faculty remained: Rains, Spector, and Westley (Herman, Vallee and Carstens eds. 1982: 71-2). The 1970s marked both the climax and, shortly after, the dénouement of McGill as the Canadian centre for SI research.

The McMaster department stepped in to assume leadership. When McMaster established its Ph.D. program in 1967-68, the department chose "the individual and society" as one of its specializations (Jones 1999). By 1975, it had a cluster of five core SI scholars: Shaffir, Ralph Matthews, Dick Brymer, Jack Haas, and Victor Marshall. As well, Marxist Peter Archibald was knowledgeable about social psychology and a sympathetic resource for SI-oriented students. For several 
years, this group supported and encouraged students who undertook SI-style research (Shaffir interview, 2002; Grills interview, 2002).

But McMaster and McGill were not the only places in Canada accommodative of SI theory and qualitative, fieldwork-based sociology during the period. Between 1960 and 1979, Canadian sociology departments hired 30 new core SI faculty and 66 SI-accommodative faculty (see Table 2). By 1979, there were 27 core SI faculty and 64 SI-accommodative faculty in departments across the country. Indeed, at least three other universities-Waterloo (Prus, Wipper, Vaz), Manitoba (Douglas, D. Albas, C. Albas) and York (Burnet, Mann, Moore)-joined McMaster as centres ("clusters") of SI activity. By 1982, eighteen of Canada's forty English-language departments of sociology or sociology/anthropology mentioned "qualitative methods," "fieldwork," "interpretive theory", "micro theory" and/or "social psychology" in either their departmental statement or their list of areas of specialization (Herman, Vallee and Carstens, eds. 1982). Most other departments had at least one faculty member who listed one of these terms as an interest or specialization. Curiously, only OISE mentioned the term "SI" among its specialty areas (Herman, Vallee and Carstens, eds. 1982: 147) and only four faculty members across the country referred to SI as a specialization (Douglas at Manitoba, Himmelfarb at UNB; Zakuta at Toronto; James Porter at York). In an especially curious development, no faculty member at any of the three best-known centres of SI-McGill, McMaster, Waterloomentioned SI as a specialty.

Table 2 (below) $)^{27}$

27. The symbol \# denotes teaching in 1979. 
TABLE 2: SI AND SI-ACCOMMODATIVE FACULTY, 1960-79,

\section{LISTED ALPHABETICALLY}

\section{CONTINUING APPOINTMENTS FROM BEFORE 1960}

Core

Burnet, J. (TO)\#; Lucas, R. (Ac, TO); Ross, A. (McG); Zakuta, L. (TO)\#

\section{SI-Accommodative}

Blishen, B. (UBC, Trent, York)\#; Cooperstock, H. (Sask, TO)\#; Elkin, F. (McG, TO)\#; Giffen, P.J. (TO)\#; Hall, O. (TO); Jones, F. (McM)\#; Keyfitz, N. (TO); Naegele, K. (UBC); Solomon, D. (McG)\#; Westley, W. (McG)\#

\section{Total: Core $4+$ SI-Acc $10=14$}

Number still teaching in 1979: Core $2+$ SI-Acc $7=9$

\section{NEW APPOINTMENTS 1960-79}

Core

Albas, C. (UMan)\#; Albas, D. (UMan)\#; Anderson, N. (MUN, UNB); Brotz, H. (McM)\#; Brymer, R. (McM)\#; Dietz, ML. (Wind)\#; Douglas, L.F. (Man)\#; Felt, L. (McG, TO, MUN)\#; Haas, J. (McM)\#; Hanigsberg, W. (McG); Himmelfarb, A. (UNB)\#; Hornosty, R. (McM)\#; House, J.D. (Calg, MUN)\#; Lee, J.A. (TO)\#; Mann, W. E. (UWO, York)\#; Marshall, V. (McM)\#; Matthews, R. (MUN, McM)\#; Maxwell, M. (Qu)\#; Maxwell, P. (Qu)\#; McKinnon, N. (Guelph)\#; Moore, J (York)\#; Prus, R. (Wpg, Wind, Wat)\#; Rains, P. (McG)\#; Shaffir, W. (McM)\#; Smith, M. (York)\#; Spector, M. (McG)\#; Stebbins, R. (MUN, Calg)\#; van den Hoonaard, W. (UNB)\#; West, G. (OISE); Wipper, A. (Wat)

\section{SI-Accommodative}

Adam, B. (Wind)\#; Archibald, P. (UWO, McM)\#; Bakker, H. (Gue)\#; Baldus, B. (TO)\#; Beattie, C. (York); Blum, A. (York)\#; Bodemann, M. (TO)\#; Boldt, E.D. (Man)\#; Boughey, H. (TO)\#; Buckner, H.T. (SGW/Conc)\#; Carveth, D. (York)\#; Christiansen-Ruffman (St.M)\#; Chua, B.H. (Trent)\#; Clairmont, D. (Guel, Dal)\#; Connelly, P. (St. M)\#; Crysdale, S. (York)\#; Curtis, J. (Wat)\#; Davies, I (Queen's, York); Effrat, A. (OISE)\#; Eglin, P. (WLU)\#; Elliott, J.L. (Dal)\#; Fleming, C.E.B. (McM, MtA)\#; Frank, A.W. (Calg)\#; Greenaway, K. (Ac, Wpg)\#; Gruneau, R. (Qu)\#; Harvey, E.B. (TO, OISE)\#; Hayduk, L. (UWO)\#; Heap, J.L. (OISE)\#; Hedican, E.J. (GUE)\#; Henshel, R.L. (UWO)\#; Herman, K. (Qu)\#; Hughes, F. (Carl)\#; Knight, D. (WLU)\#; Kueneman, R. (Man)\#; Lambert, R. (Wat)\#; Lodhi, A. (UW)\#; Lustigman, M. (Bish)\#; Macdonnell, A.J. (UNB)\#; Mackie, M. (Calg)\#; Magill, D. (TO)\#; McCormack, T. (York)\#; McHugh, P. (York)\#; McKay, R. (TO)\#; Nock, D. (Lake)\#; O’Neill, J. (York)\#; Paasche, G. (York)\#; Porter, Jim (York)\#; Ratner, R. (UBC)\#; Richardson, C.J. (Bish, UNB)\#; Richer, S. (Carl)\#; Shuraydi, M. (Wind)\#; Silverman, R.A. (UWO, AB)\#; Silvers, R.J. (OISE)\#; Sinclair, P. (Gue)\#; Smith, D. (UBC, OISE)\#; Steffens, C. (Carl)\#; Stein, A. (TO)\#; Stoddard, K. (UBC)\#; Tan, B. (Qu)\#; Tepperman, L. (TO)\#; Turk, J. (TO)\#; Turner, R. (UBC)\#; Vaz, E. (Wat)\#; Weeks, P. (StTh)\#; Westhues, K. (Guel, UWO, Wat)\#; Whittaker, E. (UBC)\#

Total Appointed 1960-79: Core 30 + SI-Acc 66 = 96

Number still teaching in 1979: Core $27+$ SI-Acc $64=91$ 
SI-based or SI-compatible publications became more prevalent in Canada's mainstream sociology journals, the CRSA and the CJS, during the period. Of the 67 articles we reviewed from the $C R S A, 1964-1979$, and the 73 we reviewed from the CJS (overall $\mathrm{n}=140$ ), fifteen-i.e. $11 \%$-were SI or SI-friendly. The six from the CRSA included Lucas (1968), Stebbins (1969), M. Smith (1975), Greenaway (1976), Heap (1978), and Baldus and Tribe (1978). The nine articles from the CJS included House (1975), R. Henshel and Silverman (1975), Tepperman (1975), Hayduk (1976), P. Connelly and Christiansen-Ruffman (1977), McKay (1978), Ellis (1979), M. Smith (1979), and Eglin (1979).

Canadian readers and textbooks also used more SI-style research. From 1960 to 1979, scholars at Canadian universities produced nineteen introductory sociology/ Canadian Society reader-textbooks. They produced only four before 1970 (Rossides 1968; Card 1968; Blishen et al, eds. 196828; Mann, ed. 1968). Only the latter two showed any influence of SI-type sociology. The 1968 edition of Canadian Society had 55 chapters. Eighteen involved fieldwork (observation combined with interviews) and six employed participant observation. Few of the essays used much theory and of the theorists cited Weber (28) and Parsons (9) were most prominent. The index had no references to SI, Cooley, or Mead. Thomas was mentioned three times and Blumer once. By contrast, of the 47 papers in Mann's volume, thirteen either reported the results of fieldwork-based studies or spoke in a favourable way about fieldwork methods (re the latter, see Tilly 1967). Among the pieces Mann reprinted, three were his own SI-oriented research (re slums [1961], students [1967a], prisons [1967b]). Four others - two excerpts from Seeley, Sim and Loosely's Crestwood Heights (1956), two pieces by Stewart Crysdale (1965a, 1965b) dealing with urbanism and working class life - were SI in tenor if not explicitly SI in character. ${ }^{29}$

The breakthrough came the next decade. Of the fifteen introductory texts that came out in the seventies, ten were pitched at the structural level and paid little or no attention to interpretive theory or issues of the self, sense-making, small group dynamics, etc. (Ossenberg, ed. 1971; Boydell, Grindstaff and Whitehead, eds. 1971; Gallagher and Lambert, eds. 1971; Rocher 1972; Fearn 1973; Hiller 1976; Ramu and Johnson, eds. 1976; Glenday, Guindon and Turowetz, eds. 1978; Fry, ed. 1979; Marsden and Harvey 1979).

28. The Blishen et al reader came out in four editions: 1961, 1964, 1968 and 1971. The last edition was an abridged version of the 1968 edition, so it represented nothing new or different. We use the 1968 edition as an indicator of the editors' view of the state of the art at the end of the 1960s.

29. We indicate the original date of publication of the book/chapter/article mentioned. 
However, five new texts-Davies and Herman, eds. (1971), Crysdale and Beattie (1973), Forcese and Richer, eds (1975), Himmelfarb and Richardson (1979), Haas and Shaffir, eds (1978) — demonstrated that SI had made it into the theoretical mainstream of Canadian sociology. Even the least SI-oriented volume among them, the Forcese and Richer collection, included a discussion of socialization that leaned heavily on the work of Mead (1975: 38-44) and contained an SI-based chapter on deviance written by Ed Vaz (1975: 303-40). The Crysdale and Beattie book and the Himmelfarb and Richardson volume were even more SI-friendly/ oriented. In each case, the editors mentioned SI as one of the standard social psychological/interpretive orientations employed by sociologists (Crysdale and Beattie 1973: 21-2, 28-9; Himmelfarb and Richardson 1979: 86-111). Indeed, Crysdale and Beattie referred to SI as "widely used in published English-Canadian studies" (1973: 28) and listed about three dozen interpretive theorists in their bibliography. The Himmelfarb and Richardson text not only contained extensive discussions of topics such as socialization, the self, labelling, etc, and drew on Cooley, Mead, Blumer, Goffman, and Becker (1979: 16-17, 86-104), but also offered a description of participant observation and ethnomethodology (1979: 30-34, 108-10). The Davies and Herman reader, Social Space: Canadian Perspectives, contained 42 essays. Seven were written by interactionists or SI-accommodative/friendly sociologists teaching at Canadian universities (i.e. O’Neill 1968; Cook 1969; Stebbins 1969; Lee 1970; Maxwell and Maxwell 1971; Latowsky and Kelner 1971; D. Smith 1971). ${ }^{30}$

By far the most significant book, though, was the Haas and Shaffir edited volume, Shaping Identity in Canadian Society (1978) - the first Canadian sociology textbook written from an exclusively SI point of view. In their introduction, the editors argued that their use of "identity" as a unifying theme allowed them to integrate a detailed analysis of the formation of individual identity with what they referred to as "an organizational and historical/structural analysis of Canadian society" (including such topics as social class and political economy) (1978: xi). The book contained twenty readings, three of which were SI standards - the most important of them Blumer's "Society as Symbolic Interaction" (1962) (also Thomas 1923; Hughes 1951). Some readings were new (Turowetz and Rosenberg 1978; Haas 1978). Some were theoretical (Shibutani 1955). Some were empirical (e.g. Ross 1954b; Chappell 1978; Lamy 1978; Felt and Berkowitz 1978; Haas and Shaffir 1978). ${ }^{31}$ Contributors drew on a variety of interpretive theorists and the empirical studies employed several research

30. We indicate the original date of publication of the book/chapter/article mentioned.

31. We indicate the original date of publication of the book/chapter/article mentioned. 
techniques: observation (participant and otherwise), interviews, autoethnography, and the analysis of secondary data. Not all of the contributors were sociologists and not all had positions at Canadian universities, but the volume demonstrated incontrovertibly that SI had arrived.

SI was institutionalized not just in terms of faculty appointments and a profile in mainstream journals and textbooks, however. As well, SI-oriented courses, graduate and undergraduate alike, began to appear in university calendars. We examined calendars from ten major universities - Alberta, UBC, McGill, McMaster, Queen's, Toronto, Waterloo, Western, Windsor and York - and discovered that by the early 1970s most of these universities had either a fieldwork or ethnography course or (more commonly) a methods course with a fieldwork/qualitative methodology component. As well, by the mid-to-late seventies, most of these universities offered a theoretical or substantive course that specifically mentioned Mead, Blumer, or SI in the course description or title. Nonetheless, as late as 1979-80, only a handful of universities-McGill, McMaster, Toronto, Waterloo and Windsor-had SI-dedicated courses.

TABLE 3: SI AND SI-ACCOMMODATIVE COURSES (UNDERGRADUATE/

GRADUATE), SELECTED MAJOR UNIVERSITIES, BY DATE OF FIRST

APPEARANCE, 1960-79

$\begin{array}{llll}\text { University } & \text { Fieldwork }^{1} & \text { SI in Course Description } & \\ \text { Alberta } & 1967-68 & 1969-70 & \text { SI Course Title } \\ \text { UBC } & 1969-70 & 1973-74 & \text { Not Applicable } \\ \text { McGill } & 1953-54^{3} & 1967-68 & \text { NA } \\ \text { McMaster } & 1973-74 & 1976-77 & 1977-78 \\ \text { Manitoba } & 1971-72 & 1971-72 & \text { NA } \\ \text { OISE } & 1971-72 & 1971-72 & \text { NA } \\ \text { Queen's } & 1970-71 & 1968-69 & \text { NA } \\ \text { Toronto } & 1976-77 & 1968-69 & \text { NA } \\ \text { Waterloo } & 1967-68 & 1977-78 & 1976-77^{4} \\ \text { Western } & 1971-72 & 1973-74 & 1977-78 \\ \text { Windsor } & 1968-69 & 1968-69 & \text { NA } \\ \text { York } & 1975-76 & 1969-70 & 1973-74 \\ \end{array}$

\footnotetext{
${ }^{1}$ Either a methods course that mentions fieldwork, ethnography or participant observation or a 
By 1979, then, SI's profile had grown substantially. There were about ninety SI or SI-accommodative faculty teaching in sociology departments across Canada, nearly a third of whom were core members of the SI community. Nineteen graduate departments of sociology had a node of at least three SI or SI-accommodative members who could help supervise SI-based theses: Alberta, UBC, Brock, Calgary, Carleton, Concordia, Guelph, Manitoba, McGill, McMaster, Memorial, UNB, Queen's, Toronto (OISE), Toronto, Waterloo, Western, Windsor, and York. As well, most major departments had a complement of coursestheoretical, methodological, substantive - that would allow an interested student to develop sufficient familiarity with SI that he or she could pursue SI-oriented thesis research. And there were other indicators as well. Mainstream texts were paying increased attention to SI. Interactionists were publishing more research. Shaffir and Haas had produced an SIbased general sociology text and a number of SI (or at least partially SIfriendly) textbooks intended for specialty areas such as social problems and deviance had been published (Boydell, Grindstaff and Whitehead 1972; Henshel and Henshel 1973; Haas and Shaffir, eds. 1974; Vaz and Lodhi 1979). In 1980, Shaffir, Robert Stebbins and Alan Turowetz published the first Canadian qualitative methods text.

Despite these positive developments, SI remained a second-tier approach and its modest core of proponents had yet to come together as a true community in intellectual or organizational terms. This was partly a function of geography. Interactionists were scattered across the country and with the exception of the group at McMaster, and the smaller concentrations at Waterloo, McGill, Queen's and Manitoba, core SI members were sometimes isolated within their own departments (Shaffir interview 2002; Stebbins interview 2002). In the days before cheap long-distance phone service, the Internet, and relatively inexpensive air travel, communication and face-to-face contact was sporadic (Stebbins interview, 2002; Shaffir interview, 2002). Both cause and effect of this situation was that the community had no official SI association, journal, or dedicated conference. Most interactionists attended the meetings of American associations such as the Society for the Study of Symbolic Interaction. Not until the mid-1970s did Canadian interactionists begin to address this deficiency by organizing regular sessions at the meetings of the CSAA (Stebbins interview, 2002).

Moreover, as we noted above, Canadian sociology had long exhibited a strong macrosociological and historical bent. This tendency was reinvigorated and reinforced when, in 1965, early in the second stage of SI's institutionalization in Canada, John Porter published The Vertical Mosaic. Porter's ground-breaking study of class and power in 
Canada probably delayed the development of SI and other interpretive approaches somewhat because, as Robert Brym has pointed out, The Vertical Mosaic essentially "set the agenda of Canadian sociology for the next decade and a half" (1989: 92). During this period, macrosociology - functionalism, the elite studies tradition, Marxism, dependency theory, various forms of feminism, the new political economy-held centre-stage in the discipline (Nock 2001: 477-81; Fisher 2010: 18-22, 25-7; Stokes and McLevey 2016: 186-8). The main preoccupation of the discipline came to be the documentation and critique of broad national and international patterns of class, ethnic, gender, regional and other forms of inequality, exploitation, and dependency (Brym 1989). In this environment, proponents of structuralist theoretical approaches regarded SI as an apolitical, microsociological perspective with limited utility for understanding Canada's key problems (Prus interview, 2002; Curtis interview, 2002)

If in the United States SI had achieved specialty status - indeed, had become a pillar of mainstream sociology — in Canada the breakthrough was delayed, first, by the late development of Canadian sociology as a whole and, then, by the largely macrosociological orientation the discipline assumed. At the end of the 1970s, Canadian SI was just moving into Mullins' specialty stage. A new cluster had formed at McMaster and, as Stokes and McLevey's data indicate, the basic principles of interpretive theory (including SI) and qualitative methods were widely accepted in the discipline. The SI community had nearly three dozen core members, several universities had SI-accommodative graduate programs, and members of the community had created a loose communication grid. As it turned out, however, the situation was about to change yet again.

\section{Conclusion: Twilight Years?}

Sometime in the early eighties, after a long period of growth as measured by the indicators of institutionalization we have used here, SI, especially in its Blumerian variant, entered a phase of decline and deinstitutionalization. Though we have not documented the features of this period in detail, we would suggest the following.

For a while after 1980, the SI community went about its business, basking in the glow of its increased institutional footprint. The centre of the approach shifted to McMaster, where the complement of core SI faculty peaked at seven in the late 1970 s and early 1980 s. $^{32}$ Indeed, as late as 2000 , there remained about a half-dozen SI or SI-accom- 
modative faculty ${ }^{33}$ and for a number of years thereafter McMaster remained "the place to go" for SI-type training in Canada (Shaffir interview 2010; D. van den Hoonaard interview 2010; W. van den Hoonaard interview 2010). Every year McMaster attracted a large cohort of graduate students interested in interpretive theory and qualitative methods. Once in the program, scores of PhD students took the "Individual and Society" comprehensive exam (Pawluch interview 2010), and many graduate students wrote an SI-oriented thesis. SI faculty produced a regular stream of articles and books, some co-authored, in many substantive areas in the discipline.

In 1984, in what might be seen as a final indicator of the institutionalization of the perspective, key figures in the SI community, led by Bob Prus at the University of Waterloo, established a highly successful annual "SI" conference, currently known as the Qualitative Analysis Conference (hereafter QAC; about which, more below).

However, even as they enjoyed these successes, the disciplinary tapestry interactionists had woven began to unravel. Stokes and McLevey's data suggest that from 1985 to 1994 SI retained its status as a specialty area but became less dense and interconnected (2016: 18890). This suggests, perhaps, the process of de-institutionalization had begun. In this respect, developments in Canada resembled developments south of the $49^{\text {th }}$ parallel. Indeed, we believe that with some caution we can apply Fine's analysis of SI's fate in the US (described in terms of the processes of fragmentation, expansion, incorporation and adoption) to the Canadian case. ${ }^{34}$

Beginning sometime in the eighties, and especially after 2000, Canadian SI began to fragment, so that the overall approach lost its "center." At the same time, proponents of SI both stepped outside the boundaries of the approach to expand the range of topics traditionally dealt with by classical SI and incorporated theoretical insights from other perspectives - especially postmodernism and feminism-into the SI edifice. "[Between 1995 and 2004], there were considerable changes in the microsociological research cluster, which in previous decades was split primarily between SI and ethnomethodology.... [T] here was more feminist literature being co-cited with qualitative data analysis books (e.g. on grounded theory), while classics in SI were much less central" (Stokes and McLevey 2016: 192). In a related

33. Among them were long-time faculty members Peter Archibald, Dorothy Pawluch, Charlene Miall, Vic Satzewich, and Billy Shaffir.

34. Vannini argues that something similar happened in Italy and the UK (2008: 8-9; citing Giampetro Gobo and Robert Dingwall, respectively). 
development, SI was infiltrated from the outside-adopted by other perspectives such as Marxism — so that its "periphery" no longer "belonged" to SI alone. These developments troubled traditional SI scholars and led them to be more vocal about policing the boundaries of the perspective (see Pawluch interview 2010; March interview 2010), but the community largely ignored such pleas. By 2000, SI, as a distinct and unified perspective, appeared to be in decline.

An illustration of this development is the transformation of the QAC. We noted above that, when first established, it was a final indicator of the institutionalization of SI in Canada. The first meeting of what came to be the QAC was held at the University of Waterloo and organized by Bob Prus. The title of the conference; i.e. "Deviance in a Cross-Cultural Context: An Ethnographic/ Interactionist Perspective," illustrated the classically interactionist character of the enterprise. Over the years, the QAC served as an important annual event for those who shared SI sensibilities and sympathies. It was the first Canadian forum devoted exclusively to qualitative research and provided practitioners of SI and related perspectives with an opportunity to meet and share their research on Canadian soil (Grills, ed. 1998: preface, v). This helped create mutual awareness among Canadian interactionists, and brought graduate students into the SI fold (Grills interview, 2002; Prus interview, 2002; Stebbins interview, 2002; March interview 2010). Early on, scholars who labelled themselves as "symbolic interactionists" in the classic Blumerian sense dominated the meetings (Bakker interview, 2010; see Vannini 2008: 8). For the first few years, Waterloo and McMaster, bastions of traditional SI, hosted the event. Eventually, however, the QAC became a victim of its own success. Over the years, as the community began to share responsibility for organizing the annual get-together (York, Carleton, UNB, Windsor and Toronto took turns hosting), an increasing number of attendees no longer fit the Blumerian profile, illustrating the influence of the processes of fragmentation, expansion, incorporation, and adoption. The theoretical scope of the conference broadened to include work from a variety of interpretive traditions, including feminism, post-modernism, and cultural analysis (Bakker interview 2010; March interview 2010). Likewise, where in the early days most papers presented at the QAC were based on traditional ethnography, by 2000 researchers presented papers based on all manner of qualitative (and other) research techniques. In short, as in the US (Fine 1993: 66), scholars practised SI in ways not linked to the once dominant Blumerian version. Some core members continued to follow "the old ways" but such work be- 
came less recognizable as the main task of the approach. Phenomenological, ethnomethodological, feminist and post-modernist forms of interpretive theory and qualitative methods began to swamp the SI ship (March interview 2010). Ironically, the QAC, an institution intended to provide an incubator and a haven for SI, came to be a site for its transformation.

Changes in the community of scholars attending the QACyounger, more theoretically diverse and methodologically eclecticreflected changes in the broader community of interpretive-constructionist sociologists. This was partly a consequence of demographics. Many "old school" interactionists have retired. Some are reaching retirement age. Certainly, this is the case at McMaster. As well, shifting departmental priorities at McMaster have put its status as the centre of SI in Canada in doubt (Milne and Helmes-Hayes, 2010). Stokes and McLevey's analysis indicates that this generational shift in approaches is not unique to SI $(2016: 192,194,196)$.

Today, feminists, postmodernists and those who, following Bourdieu in particular, have taken the "cultural turn," seem to have substantial control over the agenda and style of interpretive-constructionist sociology. Two recent empirical studies bear this out. According to Stokes and McLevey, "English-Canadian sociology has reorganized around a different set of specialties.... Bourdieu's work knits many but not all of the specialties and research agendas together" (2016: 195). ${ }^{35}$ Joseph Michalski's data, reported in "The epistemological diversity of Canadian sociology," support Stokes and McLevey's claims about the increased prominence of feminism, the study of gender and gender inequality, and interpretive methods, but do not offer support for their claim about the prominence of postmodernism. Michalski's data, based on responses from a national sample of English-language sociologists, indicate that, in 2015, $11 \%$ of Canadian sociologists chose interpretive social science as their sole "main research approach" and $44 \%$ chose it as one of their "main research approaches" (539). However, though Stokes and McLevey argue that "the sociology of culture cluster" is at the centre of English-language sociology, Michalski finds that only $18 \%$ of sociologists identified as "adherents of postmodernism, poststructuralism or cultural studies" - and almost all of them identified as/chose one or more of the "critical, feminist, and /or interpretive" research approaches as well (540). Indeed, the dominant

35. They follow this up with a more detailed analysis of the "uneven influence" of Bourdieu in Anglophone sociology (McLevey, Stokes and Howard in press). 
image that emerges from Michalski's data is a discipline populated by scholars with a broadly "critical" (i.e. "social justice") orientation who are also drawn to various forms of interpretive, feminist, and postmodern thought. In this environment, there is some doubt whether SI in its Blumerian form will make a comeback. There are those (Vannini 2008; Charmaz 2008) who think that in one form or another SI has a great deal to offer. But some interactionists are quite pessimistic about the fate of classical SI. In the words of Antony Christensen: "I don't know if it [SI] has much ... future anywhere in terms of people explicitly calling themselves that" (interview 2010). Hans Bakker was even more direct: "If you wanted to be really radical about it, you could say SI is dead" (interview 2010).

Despite these claims, we hesitate to write an obituary for classical SI. We think it will retain some devotees, at least for another generation. Evidence from Stokes and McLevey indicates that after 2005 "classical SI work ... once again [became] central to research clusters focussed on qualitative methods." This is encouraging for classical SI types because Blumer, along with Goffman, Corbin, and Glaser and Strauss, are close to the core of the sociology network. But there are two "flies in the ointment." The first is that this resurgence is not because SI-inspired ethnographies have become central or that SI theory is especially central, but because people are interested in qualitative methods, including SI. Jennifer Platt notes in this regard that during the 1980s and 1990s, the percentage of empirical articles published in the CRSA and CJS and based on qualitative methods jumped from 6 $\%$ to $43 \%$ (2006: 214; Table 4; see also $212 \mathrm{n}$. 15). The percentage of empirical articles rooted in "interviews" and "participant observation" increased from $8 \%$ and $4 \%$, respectively, in the eighties to $18 \%$ and $5 \%$, respectively, in the nineties (213; Table 3). Most of this increment was a consequence of the increased use of qualitative methods by female sociologists (218). The second issue is that the SI works that are co-cited are often cited in tandem with works in the sociology of culture, in particular, the work of Bourdieu (Stokes and McLevey 2016: 194-5). So scholars seem to be drawing on the methodology, not the theory of SI. That said, it is important to note that there has long been a powerful sect-like quality to SI. ${ }^{36}$ This deep commitment to SI allowed less than three dozen enthusiasts to alter the discipline in a significant way. Such zeal is not likely disappear, though it is also unlikely that the strong convictions of a dwindling number of Blumerians

36. Both Shaffir (interview 2010) and Puddephat (interview 2010) mentioned the "sectarian" character of SI. 
will save the perspective in its classical form. Interviews with a handful of more recent cohorts of sociologists trained and hired after 2000, and who regard themselves as within the SI fold, suggest that they are untroubled by the fading away of classical SI. They respect the contributions of earlier generations of interactionists, but do not share some of the convictions of the founders and, thus, no longer feel a need to self-identify as "symbolic interactionists." As Tony Puddephatt put it: "The new forms of SI are starting to link either with postmodernism ... or more mainstream methods and theories.... People are more openminded. I think the intellectual presence [of SI] will be become more diffused. It used to be important to have it as a separate, autonomous thing, ... but I think that age is over" (2010 interview). In our view, this means that classical SI is in the process of de-institutionalization while other forms of interpretive-constructionist sociology, especially postmodernism, are taking its place. In fact, we would say that in the current environment, in which: $\mathrm{i} / \mathrm{forms}$ of interpretive theory have a high profile; ii/ qualitative research is very popular; and iii/ interdisciplinary training and research are prevalent, SI is "unnecessary" as a stand-alone perspective. Along with other interpretive approaches, SI brought issues such as the self, meaning construction, intersubjectivity, and the like into the limelight. Indeed, such was its influence that the consideration of these issues became standard practice in the discipline.

But SI's success had a price. Over the years, interactionists connected with a wide range of somewhat likeminded theorists - ethnomethodologists, phenomenologists, feminists, postmodernists - but in the process classical SI seems to have been all but subsumed. This slow fade is profoundly ironic, for it is the unintended consequence of three things: the strength with which classical interactionists held their original convictions, the wisdom of the message they preached, and the zeal with which they worked to achieve their goal. 


\section{REFERENCES}

\section{Interviews}

By Emily Milne: Hans Bakker (May 2010), Tony Christensen (May 2010), Karen March (June 2010), Dorothy Pawluch (January 2010), Tony Puddephat (May 2010), William Shaffir (January 2010), Deborah van den Hoonaard (June 2010), Will van den Hoonaard (May 2010)

By Fatima Camara: Bob Prus (March 2002), James Curtis (April 2002), Scott Grills (March 2002), William Shaffir (March 2002), Robert Stebbins (March 2002),

By Rick Helmes-Hayes: Jean Burnet (February 1995), Leo Zakuta (March 1995)

\section{Archival Sources}

McGill University Archives, Faculty of Arts and Science

University Calendars: Acadia, Alberta, Bishop's, British Columbia, Brock, Calgary, Carleton, Concordia, Guelph, Lethbridge, Manitoba, McGill, McMaster, Memorial, Mount St. Vincent, New Brunswick, OISE, Queen's, Saskatchewan, Simon Fraser, St. Mary's, St. Thomas, Toronto, Trent, Victoria, Waterloo, Western Ontario, Wilfrid Laurier, Windsor, Winnipeg, York

\section{Other Sources}

Abbott, Andrew. 1997. Time and Space: The contemporary relevance of the Chicago School. Social Forces 75 (4): 1149-82.

Baldus, Bernd and Verna Tribe. 1978. The development of perceptions and evaluations of social inequality among public school children. Canadian Review of Sociology and Anthropology 15 (1): 50-60.

Bayley, Charles. 1934-35. Social Institutions, taught by Everett Hughes [lecture notes]. McGill University, [privately held, R. Helmes-Hayes].

.1934-35. Sociology of the Child, taught by Everett Hughes [lecture notes]. McGill University, [privately held, R. Helmes-Hayes].

Becker, Howard S. 1963. Outsiders. New York: Free Press.

.1970. Sociological Work. Chicago: Aldine.

Bernard, L.L. 1909. The teaching of sociology in the United States. American Journal of Sociology 15 (2): 164-213.

Blishen, Bernard, Frank Jones, Kaspar Naegele, and John Porter, eds. 1961, 1964, 1968, 1971 [abridged]. Canadian Society. Toronto: Macmillan. 
Blumer, Herbert. 1938. Social psychology. In Man and Society, edited by E. P. Schmidt, 144-98. Englewood Cliffs, NJ: Prentice-Hall.

. 1962. Society as symbolic interaction. In Human Behavior and Social Processes, edited by A.M. Rose, 179-192. Boston: Houghton-Mifflin.

Bodemann, Michal. 1984. Elitism, fragility and commoditism: Three themes in the Canadian sociological mythology. In Models and Myths in Canadian Sociology, edited by Steve Berkowitz, 211-31 .Toronto: Butterworth.

Boydell, Craig, Carl Grindstaff and Paul Whitehead. eds. 1971. Critical Issues in Canadian Society. Toronto: Holt Rinehart and Winston.

1971. Deviant Behaviour and Societal Reaction. Toronto/Montreal: Holt, Rinehart and Winston.

Brym, Robert. 1979. New directions in Anglo-Canadian historical sociology. Canadian Journal of Sociology 4 (3): vii-xi. . 1986. Anglo-Canadian sociology. Current Sociology 34 (1): 1-152. (with Bonnie Fox). 1989. From Culture to Power. Toronto: Oxford.

Bulmer, Martin. 1984. The Chicago School. Chicago: University of Chicago Press.

Burnet, Jean. 1947. Town-country relations and problems of cultural leadership. Canadian Journal of Economics and Political Science 13 (3): 395-409. 1951. Next-Year Country. Toronto: University of Toronto Press.

Cahiers de Recherche Sociographique 39 2003, entire issue.

Camara, Fatima, and Rick Helmes-Hayes. 2003. Tracing the historical development of symbolic interactionism in Canada. Paper presented at the Qualitative Analysis Conference. Carleton University, Ottawa, ON.

Canada. Dominion Bureau of Statistics. 1921. Canada Year Book 1920. Ottawa: King's Printer.

. Statistics Canada. 1984. Education Statistics for the Seventies 1979. Ottawa: Queen's Printer.

. Statistics Canada. 1996. A Statistical Portrait of Education at the University Level in Canada. Catalogue No. 81-579-XPB. Ottawa: Canadian Educational Statistics Council.

Canadian Journal of Sociology 26 (3) 2001, entire issue

Canadian Review of Sociology and Anthropology 18 (5) 1985, entire issue.

Card, B. Y. 1968. Trends and Change in Canadian Society. Toronto: Macmillan.

Carroll, William K. 2013. Half a century of sociological scholarship in the CRS(A). Canadian Review of Sociology 50 (3): 239-55. 
Chappell, Neena. 1978. Senility: Problems in communication. In Shaping Identity in Canadian Society, edited by J. Haas and W. Shaffir, 65-86. Scarborough, Ontario: Prentice-Hall.

Charmaz, Kathy. 2008. A Future for SI. In Studies in Symbolic Interaction 32, edited by Norman Denzin, James Salvo and Myra Washington, 51-9; published online by Emerald Publishing; http://dx.doi.org/10.1016/

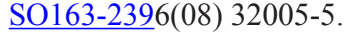

Charon, J. 1992. Symbolic Interactionism. $4^{\text {th }}$ ed. Englewood Cliffs, NJ: Prentice-Hall.

Clark, S. D. 1975. Sociology in Canada: An historical overview. Canadian Journal of Sociology 1 (1): 225-34.

. 1979. The changing image of sociology in English-speaking Canada. Canadian Journal of Sociology 4 (4): 393-403.

Connelly, Patricia and Linda Christiansen-Ruffman. 1977. Women's problems: Private troubles or public issues. Canadian Journal of Sociology 2 (2): 167-78.

Connor, Desmond M. 1968. Sociologists and Anthropologists in Canada and their Current Research. Montreal: Canadian Sociological and Anthropological Association.

and Jim Curtis. 1970. Sociology and Anthropology in Canada: Some Characteristics of the Disciplines and their Current University Programs. Montreal: Canadian Sociology and Anthropology Association.

Cook, Shirley. 1969. Canadian narcotics legislation, 1908-1923: A conflict model interpretation. Canadian Review of Sociology and Anthropology $6(1): 36-46$.

Cooperstock, Henry. 1961. Co-operative farming as a variant social pattern. In Canadian Society, edited by Blishen et al., 256-74. Toronto: Macmillan.

Cormier, Jeffery. 2004. The Canadianization Movement. Toronto: University of Toronto Press.

Couch, Carl. 1968. Collective behaviour: Examining some stereotypes. Social Problems 15 (2): 310-22.

and Robert Hintz, eds. 1975. Constructing Social Life. Champaign, Ill: Stipes.

Crane, Diana. 1967. The gatekeepers of science: Some factors affecting the selection of articles for scholarly journals. The American Sociologist 2 (4): 195-201.

1972. Invisible Colleges. Chicago: University of Chicago Press.

Crysdale, Stewart. 1965a. Urbanism and its relation to religious and theological perspectives. In Crysdale, ed., The Changing Church in Canada. Toronto: Evangelism Resource Committee, Board of Evangelism and Social Service, United Church of Canada. 
1965b. Social Effects of a Factory Relocation. Toronto: ReligionLabour Council of Canada, United Steelworkers of America.

and Christopher Beattie. 1973. Sociology in Canada. Toronto: Butterworth.

Davies, D.I. and Kathleen Herman, eds. 1971. Social Space. Toronto: New Press.

Dawson, Carl and Warner Gettys. 1929, 1935, 1948. An Introduction to Sociology. 3 eds. New York: Ronald.

Denzin, Norman. 1989. Interpretive Interactionism. Newbury Park, CA: Sage.

Dingwall, Robert. 2001. Notes toward an intellectual history of symbolic interactionism. Symbolic Interaction 24 (2): 237-42.

Eglin, Peter. 1979. Resolving reality disjunctures on Telegraph Avenue: A study of practical reasoning. Canadian Journal of Sociology 4 (4): 359-77.

Eichler, Margit. 2001. Women pioneers in Canadian sociology: The effects of a politics of gender and a politics of knowledge. Canadian Journal of Sociology 26(3): 375-403.

Ellis, Desmond. 1979. The prison guard as cultural Luddite: A critical review of the McGuigan Report on the penitentiary system in Canada. Canadian Journal of Sociology 4 (1): 43-64.

Falardeau, Jean-Charles, and Frank Jones. 1958. La sociologie au Canada. Transactions of the $3^{\text {rd }}$ World Congress of Sociology, Amsterdam, 7, 14-22.

Faris, R. E. L. 1970. Chicago Sociology: 1920-32. Chicago: University of Chicago Press.

Fearn, Gordon. 1973. Canadian Social Organization. Toronto/Montreal: Holt Rinehart Winston.

Felt, Lawrence and Stephen Berkowitz. 1978. Elite structure and identity in Canada: A historical overview. In Shaping Identity in Canadian Society, edited by J. Haas and W. Shaffir, 278-313. Scarborough: Prentice-Hall.

Fine, Gary Alan. 1990. Symbolic interaction in a post-Blumerian age. In Frontiers of Sociological Theory, edited by George Ritzer, 117-57. New York: Columbia University Press.

. 1993. The sad demise, mysterious disappearance, and glorious triumph of symbolic interactionism. Annual Review of Sociology 19 (1): 61-87.

ed. 1995. A Second Chicago School? Chicago and London: University of Chicago Press.

Fisher, Berenice and Anselm Strauss. 1978. The Chicago tradition and social change: Thomas, Park and their successors. Symbolic Interaction 1(2): $5-23$. 
Fisher, Donald. 2010. Theoretical and methodological shifts in the discipline of sociology in English-speaking Canadian Universities, 1950s-1990s. Paper presented at the Canadian Sociology and Anthology Association Conference. Montreal, PQ.

Forcese, Dennis and Stephen Richer, eds. 1975. Issues in Canadian Society. Scarborough: Prentice-Hall.

Fournier, Marcel. 2007. Émile Durkheim. Paris: Éditions Fayard, Collection: Histoire de la Pensée.

Friedrichs, Robert. 1970. A Sociology of Sociology. New York: The Free Press.

Frost, Stanley. 1984. McGill University: For the Advancement of Learning. Vol. 2: 1895-1971. Kingston and Montreal: McGill-Queen's University Press.

Fry, John, ed. 1979. Economy, Class and Social Reality. Toronto: Butterworths.

Fulcomer, Frank. 1894. Instruction in sociology in institutions of learning. Proceedings of the National Conference of Charities and Corrections 21: $67-78$.

Gallagher, James and Ronald Lambert, eds. 1971. Social Process and Institution. Toronto/Montreal: Holt, Rinehart and Winston.

Giffen, James. 2004 [1946]. Rural Life. G. Friesen ed., Winnipeg: Winnipeg University Press.

Glaser, Barney and Anselm Strauss. 1967. The Discovery of Grounded Theory. Chicago: Aldine.

Glenday, Daniel, Hubert Guindon and Allan Turowetz, eds. 1978. Modernization and the Canadian State. Toronto: Macmillan.

Grayson, Paul and Dennis Magill. 1981. One Step Forward, Two Steps Sideways: Sociology and Anthropology in Canada. Montreal: Canadian Sociology and Anthropology Association.

Greenaway, W. 1976. Faith and science in the professional ideology of caseworkers. Canadian Review of Sociology and Anthropology 13 (1): 10613 .

Grills, Scott, ed. 1998. Doing Ethnographic Research. Thousand Oaks, London \& New Delhi: Sage Publications.

Gusfield, Joseph. 2003. A journey with symbolic interaction. Symbolic Interaction 26(1), 119-139.

Haas, Jack. 1978. Learning real feelings: A study of high steel ironworkers' reactions to fear and danger. In Shaping Identity in Canadian Society, edited by J. Haas and W. Shaffir, 227-44. Scarborough: Prentice-Hall.

and William Shaffir, eds. 1974. Decency and Deviance. Toronto: McClelland and Stewart. 
and William Shaffir, eds. 1978. Shaping Identity in Canadian Society. Scarborough: Prentice-Hall.

and William Shaffir. 1978. The professionalization of medical developing competence and a cloak of competence. In Shaping Identity in Canadian Society, edited by J. Haas and W. Shaffir, 203-26. Scarborough: Prentice-Hall.

Hall, Oswald. 1946. The informal organization of the medical profession. Canadian Journal of Economics and Political Science 12 (1):30-44.

. 1948. Stages of a medical career. American Journal of Sociology 54 (5): $327-336$.

1949. Types of medical careers. American Journal of Sociology 55 (3): $243-53$.

1964. Carl A. Dawson, 1887-1964. Canadian Review of Sociology and Anthropology 1 (2): 115-7.

Hamilton, Roberta. 2003. La sociologie féministe (1970-2003) au Canada anglais. Cahiers de recherche sociolographique, 39, 165-80.

Harvey, Lee. 1987. Myths of the Chicago School of Sociology. Aldershot: Avebury.

Hayduk, Leslie 1976. Formulations in police work: some observations and related theoretical concerns. Canadian Journal of Sociology 1 (4): 463-79.

Heap, James. 1978. Warranting interpretation: a demonstration. Canadian Review of Sociology and Anthropology 15 (1): 41-9.

Helmes-Hayes, Rick, ed. 1988. A Quarter-Century of Sociology at the University of Toronto 1963-1988. Toronto: Canadian Scholars' Press.

1994. Canadian sociology's first textbook: C.A. Dawson and W.E. Getty's An Introduction to Sociology (1929). CJS 19 (4): 461-497.

. 1998. Everett Hughes: Theorist of the second Chicago School. International Journal of Politics, Culture and Society 11 (4): 621-73.

.2003. 40 Years, 1963-2003: Department of Sociology, University of Toronto. Toronto: Canadian Scholars' Press.

.2010. Measuring the Mosaic. Toronto: University of Toronto Press.

. 2014. Coral W. Topping, pioneer Canadian public sociologist: "A veteran warrior for prison reform." In The Public Sociology Debate, edited by C. Schneider and A. Hanemaayer, 175-202. Vancouver: UBC Press.

2016. "'Building the New Jerusalem in Canada's green and pleasant land': The social gospel and the roots of English-language sociology in Canada, 1889-1921". Canadian Journal of Sociology 41 (1): 1-52. 
and Jean-Philippe Warren. In press. The development of Canadian sociology. In The Cambridge Handbook of the History of Sociology, edited by Kathleen Korgen, Cambridge University Press.

Henshel, Richard and Anne-Marie Henshel. 1973. Perspectives on Social Problems. Don Mills: Longman's.

and Robert Silverman. 1975. Perception and criminal process. Canadian Journal of Sociology 1 (1): 33-47.

Herman, Kathleen and Peter Carstens, eds. 1978. 1978-1979 Guide to Departments of Sociology, Anthropology and Archaeology in Universities and Museums in Canada. National Museum of Man Mercury Series, Directorate paper No. 1. Ottawa: National Museum of Man and National Museums of Canada.

Herman, Kathleen, Frank Vallee, and Peter Carstens, eds. 1982. 1981-1982 Guide to Departments of Sociology, Anthropology and Archaeology in Universities and Museums in Canada. National Museum of Man Mercury Series, Directorate paper No. 2. Ottawa: National Museum of Man and National Museums of Canada.

Hewitt, John and David Shulman. 2011. Self and Society: A Symbolic Interactionist Social Psychology (11th ed). New York: Pearson.

Hiller, Harry. 1976. Canadian Society. Scarborough: Prentice-Hall.

. 1979. The Canadian sociological movement: Analysis and assessment. Canadian Journal of Sociology 4(2): 125-50.

1980. Paradigmatic shifts, indigenization, and the development of sociology in Canada. Journal of the History of the Behavioral Sciences 16 (3): 263-74.

1982. Society and Change. Toronto: University of Toronto Press.

and Linda Di Luzio. 2001. Text and context: Another 'chapter' in the evolution of sociology in Canada. Canadian Journal of Sociology 26 (3): 487-512.

and Simon Langlois. 2001. The most important books/articles in Canadian sociology in the twentieth century: A report. Canadian Journal of Sociology 26 (3): 513-6.

Himmelfarb, Alexander and James Richardson. 1979. People, Power and Process. Toronto: McGraw-Hill Ryerson.

Hoecker-Drysdale, Susan. 1990. Women sociologists in Canada: The careers of Helen MacGill Hughes, Aileen Dansken Ross, and Jean Robertson Burnet. In Despite the Odds, edited by M. Gosztonyi Ainley, 152-76. Montreal: Véhicule Press.

1996. Sociologists in the vineyard: The careers of Helen MacGill Hughes and Everett Cherrington Hughes. In Creative Couples in the Sciences, edited by H. Pycior, N. Slack, and P. Abir-Am, 221-30. New Brunswick, New Jersey: Rutgers University Press. 
House, Doug. 1975. Organization without formalization: the case of a real estate agency Canadian Journal of Sociology 1 (1): 19-32.

Hughes, Everett. 1943. French Canada in Transition. Chicago: University of Chicago Press.

1951. Work and the self. In Social Psychology at the Crossroads, edited by J. Rohrer and M. Sherif, 313-23. New York: Harper and Row.

. 1971 [1960]. Introduction: The place of fieldwork in social science. In E. Hughes, The Sociological Eye (pp. 496-506). Chicago: Aldine Atherton.

Jones, Frank. 1961. The socialization of the infantry recruit. In Canadian Society, edited by Blishen et al, 285-98. Toronto: Macmillan.

1990. Establishing the Canadian Sociology and Anthropology Association (CSAA). Society/Société 14 (3): 30-7.

. 1992. The evolution of the CSAA. In Fragile Truths, edited by W. Carroll, L. Christiansen-Ruffman, R. Currie and D. Harrison, 21-7. Ottawa: Carleton University Press.

1999. Historical Background: A Profile of our Department. McMaster University Department of Sociology website. Retrieved June 2014 from http://www.sociology.mcmaster.ca/who-we-are

Katovich, Michael, Dan Miller, and Robert Stewart. 2003. The Iowa School of symbolic interactionism. In The Handbook of Symbolic Interactionism, edited by L. Reynolds and N. Herman, 119-141. Walnut Creek, CA: AltaMira Press.

Kuhn, Manford. 1964. Major trends in symbolic interactionist theory in the past 25 years. Sociological Quarterly 5 (1): 61-84.

and Thomas McPartland. 1956. An empirical investigation of selfattitudes. American Sociological Review 19 (1): 68-76.

Kurtz, Lester. 1984. Evaluating Chicago Sociology. Chicago: University of Chicago Press.

Lal, Barbara Ballis. 1995. Symbolic interaction theories. The American Behavioral Scientist 38 (3): 421-41.

Lamy, Paul. 1978. Bilingualism and identity. In Shaping Identity in Canadian Society, edited by J. Haas and W. Shaffir, 133-40. Scarborough: Prentice-Hall.

Langford, Tom. 2013. Five decades of class analysis in the Canadian Review of Sociology. Canadian Review of Sociology 50 (3): 306-36.

Latowsky, E. and M.J. Kelner. 1971. Youth: the new tribal group. In Social Space, D. I. Davies and K. Herman, 240-3. Toronto: New Press.

Leacy, F. H., ed. 1983. Historical Statistics of Canada. Ottawa: Statistics Canada with Social Science Federation of Canada. Retrieved Aug 2013 from 
http://www.publications.gc.ca/pub?id=286224\&sl=0

Lee, John Alan. 1970. Faith Healing. Sectarian Healers and Hypnotherapy. Toronto: Queen's Printer.

Lewis, David and Richard Smith. 1980. American Sociology and Pragmatism. Chicago: University of Chicago Press.

Leznoff, Maurice and William Westley. 1956. The homosexual community. Social Problems 3 (4): 257-63.

Low, Jacqueline and Gary Bowden, eds. 2013. The Chicago School Diaspora. Montreal/Kingston: McGill-Queen's University Press.

2016. Everett C. Hughes: A key figure of the Canadian Chicago School diaspora," In The Anthem Companion to Everett Hughes, edited by Rick Helmes-Hayes and Marco Santoro, 115-32. London/New York: Anthem.

Lucas, Rex. 1968. Social implications of the immediacy of death. Canadian Review of Sociology and Anthropology 5 (1): 1-16.

Lukes, Steven. 1973. Emile Durkheim. London: Allen Lane.

Maines, David. 1977. Social organization and social structure in symbolic interactionist thought. Annual Review of Sociology 3(1): 235-59.

. 2001. The Faultline of Consciousness. 2001. New York: Aldine de Gruyter.

Mann, W. E. 1961. The social system of a slum: The Lower Ward, Toronto. In Urbanism and the Changing Canadian Society, edited by S.D. Clark, 294-310. Toronto: University of Toronto Press.

. 1967a. Sex Behavior on the Campus. Canadian Trends in Premarital Behaviour. Toronto: Council for Social Service of the Anglican Church of Canada.

.1967b. Patterns of Prisoner Social Organization. In Mann, Society Behind Bars, 57-65. Toronto: Social Science.

, ed. 1968. Canada: A Sociological Profile. Toronto: Copp Clark.

Marchak, Pat. 1985. Political economy. Canadian Review of Sociology and Anthropology 18 (5): 673-709.

Marsden, Lorna and Edward Harvey. 1979. Fragile Federation: Toronto: McGraw-Hill.

Maticka-Tyndale, Eleanor and Janice Drakich. 1992. Striking a balance: Women organizing for change in the CSAA. In Fragile Truths, edited by W. Carroll et al., 43-56. Ottawa: Carleton University Press.

Matthews, Fred. 1977. Quest for an American Sociology. Montreal and Kingston: McGill-Queen's University Press. 
Maxwell, Mary and James Maxwell. 1971. Boarding school: Social control, space, and identity. In Social Space, edited by D.I. Davies and K. Herman, 157-64. Toronto: New Press.

McKay, Robert. 1978. Assembling a corpus: The nature and process of instruction. Canadian Journal of Sociology 3 (1): 41-59.

McLevey, John, Allyson Stokes and Amelia Howard. In press. Pierre Bourdieu's uneven influence on Anglophone Canadian sociology. In the $O x$ ford Handbook of Pierre Bourdieu, edited by Thomas Medvet and Jeff Sallaz. Oxford: Oxford University Press.

Mead, G. H. 1962 [1934]. Mind, Self and Society from the Standpoint of a Social Behaviorist. C.W. Morris, ed. Chicago: University of Chicago Press.

Meltzer, Bernard, John Petras, and Larry Reynolds. 1975. Symbolic Interactionism. London: Routledge \& Kegan Paul.

Michalski, Joseph. 2016. The epistemological diversity of Canadian sociology. Canadian Journal of Sociology 41 (4): 525-56.

Milne, Emily and Rick Helmes-Hayes. 2010. The rise (and fall?) of McMaster University as the centre of symbolic interactionism in Canada, 19672010. Paper presented at the Society for the Study of Symbolic Interactionism Conference. Atlanta, GA.

Morgan, J. Graham. 1966. Sociology in America: A Study of its Institutional Development until 1900. Unpublished PhD dissertation, Oxford University.

Mullins, Nicholas (with Carolyn Mullins). 1973. Theories and Theory Groups in Contemporary American Sociology. New York: Harper \& Row.

Naegele, Kaspar. 1951. Some problems in the study of hostility and aggression in middle-class American families. Canadian Journal of Economics and Political Science 17 (1): 65-75.

.1956. Clergymen, teachers, and psychiatrists: A study in roles and socialization. Canadian Journal of Economics and Political Science 22 (1): 46-62.

Nock, David. 1988. The Chicago imprint in Canada: Oswald Hall and S.D. Clark. In Proceedings of the $28^{\text {th }}$ Annual Meetings of the Western Association of Sociology and Anthropology, edited by J. Foraker-Thompson, Boise State University, Boise, Idaho.

. 2001. Careers in print: Canadian sociological books and their impact, 1975-1992. Canadian Journal of Sociology 26 (3): 469-86.

Oberschall, Anthony. 1972. The institutionalization of American sociology. In Oberschall, ed., The Establishment of Empirical Sociology, 187-251. New York: Harper and Rowe.

O’Neill, John. 1968. Public and private space. In Agenda 1970, edited by T. Lloyd and J. McLeod, 74-93. Toronto: University of Toronto Press. 
Ossenberg, Richard, ed. 1971. Canadian Society. Scarborough: Prentice-Hall.

Ostow, Robin. 1984. Everett Hughes: The McGill years. Society/ Société 8 (3): $12-16$.

Page, Charles. 1940. Class and American Sociology. New York: Schocken.

Pakulski, Jan and Malcolm Waters. 1996. The Death of Class. London: Sage.

Parsons, Talcott. 1951. The Social System. New York: Free Press.

Platt, Jennifer. 2006. How distinctive are Canadian research methods? Canadian Review of Sociology and Anthropology 43 (2): 205-31.

Plummer, Kenneth. 1991. Symbolic Interactionism. Aldershot, Hants: Elgar. 1996. Symbolic interactionism in the twentieth century: The rise of empirical social theory. In The Blackwell Companion to Social Theory, edited by B. Turner, 223-51. Oxford: Blackwell.

Porter, John. 1965. The Vertical Mosaic. Toronto: University of Toronto Press.

Prus, Robert. 1996. Symbolic Interaction and Ethnographic Research. New York: State University of New York Press.

Ramos, Howard. 2013. From ethnicity to race in the Canadian Review of Sociology, 1964-2010. Canadian Review of Sociology 50 (3): 337-56.

Ramu, Gary and Stuart Johnson, eds. 1976. Introduction to Canadian Society. Toronto: Macmillan.

1976. Toward a Canadian sociology. In Introduction to Canadian Society, edited by Ramu and Johnson, 479-94. Toronto: Macmillan.

Reid, Stuart. 1961. Education: English Canada. In Canadian Annual Review for 1960, edited by J.T. Saywell, 243-52. Toronto: University of Toronto Press.

Reynolds, Larry and Nancy Herman-Kinney. 2003. Handbook of Symbolic Interactionism. Walnut Creek, CA: AltaMira.

Rocher, Guy. 1972. A General Introduction to Sociology. (P. Sheriff, Trans.). Toronto: Macmillan.

Rock, Paul Elliott. 1979. The Making of Symbolic Interactionism. Totawa, N.J.: Rowman and Littlefield.

Rosenau, Pauline. 1991. Postmodernism and the Social Sciences. Princeton, N.J.: Princeton University Press.

Ross, Aileen D. 1943. The cultural effects of population changes in the Eastern Townships. Canadian Journal of Economics and Political Science 9 (4): 447-62.

1952. Organized philanthropy in an urban community. Canadian Journal of Economics and Political Science 18 (4): 482-5. 
1954a. French and English Canadian contacts and institutional change. Canadian Journal of Economics and Political Science 20 (3): 281-95.

1954b. Philanthropic activity and the business career. Social Forces 32 (3): 274-80.

Rossides, Daniel. 1968. Society as a Functional Process. Toronto: McGrawHill.

Rush, G., E. Christiansen and J. Malcolmson. 1981. Lament for a notion: The development of social science in Canada. Canadian Review of Sociology and Anthropology 18 (4): 519-44.

Sandstrom, K., D. Martin and G.A. Fine. 2001. Symbolic interactionism at the end of the century. In Handbook of Social Theory, edited by G. Ritzer and B. Smart, 216-31. London: Sage.

2010. $3^{\text {rd }}$ ed. Symbols, Selves and Social Reality. New York: Oxford University Press.

Seeley, John., Alexander Sim, and Elizabeth Loosely. 1956. Crestwood Heights. Toronto: University of Toronto Press.

Shaffir, William, Robert Stebbins and Allan Turowetz, eds. 1980. Fieldwork Experience. New York: St. Martin's Press.

Shibutani, Tamotsu. 1955. Reference groups as perspectives. American Journal of Sociology 60 (6): 562-9.

Shils, Edward. 1970. Tradition, ecology and institution in the history of sociology. Daedalus 99 (4): 760-825.

Shore, Marlene. 1987. The Science of Social Redemption. Montreal and Kingston: McGill-Queen's University Press.

Smith, Dorothy. 1971. Household space and family organization. Pacific Sociological Review 14 (1): 53-78.

1987. The Everyday World as Problematic. Boston: Northeastern University Press.

. 2005. Institutional Ethnography. Lanham: AltaMira Press.

Smith, Michael. 1975. The legitimation of violence: Hockey players' perceptions of their reference groups' sanctions for assault. Canadian Review of Sociology and Anthropology 12 (1): 72-80.

1979. Towards an explanation of hockey violence: a reference other approach. Canadian Journal of Sociology 4 (2): 105-24.

Solomon, David. 1954. Sociological research in a military organization. Canadian Journal of Economics and Political Science 20 (4): 531-41.

. 1968. Sociological perspectives on occupations. In Institutions and the Person, edited by H.S. Becker et al, 3-13. Chicago: Aldine. 
n.d. My life as a teacher and student at McGill, 1935-1974. unpublished ms, McGill University Archives, Archives Information file "Sociology."

Stebbins, Robert. 1969. Social network as a subjective construct: a new application for an old idea. Canadian Review of Sociology and Anthropology 6 (1): $1-14$.

Stokes, Allyson and John McLevey. 2016. From Porter to Bourdieu: The evolving specialty structure of English Canadian sociology, 1966 to 2014. Canadian Review of Sociology 53 (2): 176-202.

Stone, Gregory and H. Farberman, eds. 1970. Social Psychology through Symbolic Interaction. Waltham, MA: Ginn Blaisdell.

Stryker, Sheldon. 1980. Symbolic Interactionism. Menlo Park, CA: Benjamin Cummings.

1981. Symbolic Interactionism: Themes and variations. In Social Psychology, edited by M. Rosenberg and R. Turner, 1-29. New York: Basic.

and Kevin Vryan. 2003. The symbolic interaction frame. In Handbook of Social Psychology, edited by J. Delamater, 3-28. New York: Kluwer.

Symons, Gladys. 1977. The use of historical models in Canadian sociology. Paper presented at the Canadian Sociology and Anthology Association Conference. Fredericton, NB.

Tepperman, Lorne. 1975. Deviance as a search process. Canadian Journal of Sociology 1 (3): 277-94.

Thomas, W.I. 1923. The definition of the situation. In The Unadjusted Girl, edited by W. I. Thomas, 41-69. Boston: Little, Brown and Company.

Tilly, Charles. 1967. Anthropology on the town. Habitat 10 (1): 20-5.

Tolman, Frank. 1902. Study of sociology in institutions of learning in the United States, parts 1 and 2. American Journal of Sociology 7 (6): 797-838.

Tomovic, Vladislav. 1975. Sociology in Canada: An analysis of its growth in English-language Universities, 1908-1972. Unpublished doctoral dissertation, University of Waterloo, Waterloo, ON.

Turowetz, Allan, and Michael Rosenberg. 1978. Exaggerating everyday life: The case of professional wrestling. In Shaping Identity in Canadian Society, edited by J. Haas and W. Shaffir, 87-99. Scarborough: PrenticeHall.

Vannini, Philip. 2008. The geography of disciplinary amnesia: Eleven scholars reflect on the international state of symbolic interactionism. In Studies in Symbolic Interaction 32 (pp. 5-18) published online by Emerald Publishing; http://dx.doi.org/10.1016/SO163-2396(08)32002-x. 
Vaz, Edward. 1975. Deviance and conformity: The issue of marijuana use. In Issues in Canadian Society, edited by Dennis Forcese and Stefan Richer, 303-40. Scarborough: Prentice-Hall.

Vaz, Edward and Abdul Lodhi. 1979. Crime and Delinquency in Canada. Toronto: Prentice-Hall.

Vienne, Philippe. 2016. The natural history of Everett Hughes: A master of fieldwork. In Anthem Companion to Everett Hughes, edited by Rick Helmes-Hayes and Marco Santoro, 93-114. London: Anthem.

Wargon, Sylvia. 2002. Demography in Canada in the Twentieth Century. Vancouver: UBC Press.

Westley, William. 1957. The nature and control of hostile crowds. Canadian Journal of Economics and Political Science 23 (1): 33-41.

Wiggershaus, Rolf. 1994. The Frankfurt School. Cambridge, UK: Polity.

Wilcox-Magill, Dennis. 1983. Paradigms and Social Science in English Canada. In Introduction to Sociology, edited by Paul Grayson, 1-34. Toronto: Gage.

Wiley,Norbert. 1979.The rise and fall of dominating theories in American sociology. In Contemporary Issues in Theory and Research, edited by W. Snizek et al., 47-79. Westport, CT: Greenwood Press.

Rick Helmes-Hayes (Department of Sociology and Legal Studies, University of Waterloo) is a historian of sociology. He has published articles about several key figures in the history of American, British and Canadian sociology. His work has appeared in inter alia Recherches sociographiques, the Canadian Review of Sociology and Anthropology, the Canadian Journal of Sociology, Sociological Quarterly, the Journal of the History of the Behavioral Sciences and the British Journal of Sociology. His most recent major work is an intellectual biography of John Porter, 'Measuring the Mosaic' (University of Toronto Press, 2010)

Email: rhh@uwaterloo.ca

Emily Milne (Department of Sociology, Grant MacEwan University). Dr. Milne's research focuses on social inequality, education, Indigenous peoples and policy. She is involved in projects that examine family/school relationships, student achievement, summer setback, the effectiveness of university learning models and curricular programs, as well as barriers to health care access. Her research has been featured on the CTV National News Channel and in CTV News, Global News, CBC, Edmonton Examiner, Metro News Edmonton, and The Huffington Post Canada.

Email: milnee4@macewan.ca 